\title{
KHITAN STUDIES \\ I. THE GLYPHS OF THE KHITAN SMALL SCRIPT
}

\section{THE CONSONANTS, 3.1 LABIAL STOPS*}

\author{
WU Yingzhe and András RÓNA-TAS \\ School of Mongolian Studies, Inner Mongolia University, \\ Höhhot 010021 China \\ e-mail:khitan1922@126.com \\ Department of Altaic Studies, University of Szeged \\ H-6722 Szeged, Egyetem utca 2, Hungary \\ e-mail: aronatas3@t-online.hu
}

This paper investigates how the Khitan Small Script renders labial stops of the Khitan language in the initial position of words and syllables. Furthermore, it deals with the problems of alloglyphs, drawings of similar shape, and denotations of the same phoneme. The paper begins with the use of glyphs in cases where they transcribe Chinese words. Evidence permitting, this is followed by the use of glyphs in cases of Chinese loanwords and names - subjects in which we have a robust background. Finally, it examines words of Khitan origin with initial labial stops. The result of our investigation is that postaspiration was the distinguishing feature in the binary opposition of labial stops. Alternation of $\langle\mathrm{b}\rangle \sim<\mathrm{p}>$ writing is common in cases where a word occurs with high frequency. To demonstrate this, we used the Khitan Corpus published in 2017.

Key words: Khitan language, Khitan Corpus, Khitan Small Script, Khitan orthography. Khitan-Uighur relations, Chinese in Khitan script, Middle Chinese reconstruction.

* This paper has been written within the framework of the Silk Road Research Group of the Hungarian Academy of Sciences, the Eötvös Loránd University Budapest and the University of Szeged. This is also the first paper written under the special co-operation between the aforementioned Research Group and the Khitan Research Group of the Chinese People's Republic, lead by Professor Wu Yingzhe (Höhhot, PRC). This paper is supported by the key programme of Philosophy and Social Science "Collation and Study of Handed-down Documents in Khitan and Jurchen" (14JZD036) of China's Ministry of Education and the project "Interpretation of the Khitan Scripts and Study on the Khitan Vocabulary" (13YJA740059) of the Humanities and Social Science Fund of China's Ministry of Education. Data marked as Wu Yingzhe (2017b) or W17b or Index are from Chinggeltei, Wu Yingzhe and Jiruhe (2017): Qidan xiaozi zai yanjiu 丹小字再研究 [Further research on Khitan Small Script]. The paper is a continuation of Khitan Studies, see RónaTas $(2016,2017)$. 


\section{Methodological Remarks ${ }^{1}$}

The Khitan Small Script (KSS) was developed around AD 925 for rendering the Khitan language, and used during the Liao and early Jin dynasties. The first known and datable text is from $\mathrm{AD} 1053^{2}$ and the last from AD $1175^{3}$. The KSS was conceived as a more or less syllabic script. During the process of deciphering, the phonetic value of the glyphs was identified with units of the contemporary Chinese phonetic system. It should be clear, however, that this could only be done in a very approximative way. The phonological structure of contemporary Chinese and that of Khitan are fundamentally different.

Yet, as all languages do, the Khitan language has at least two registers. One is a literary style that arises from the pronunciation of texts when read ${ }^{4}$. Another register is the daily spoken language which existed beneath the literary style. At present, we can only try to reconstruct the reading style of Khitan from the writing system. Even this has its constraints. The Khitan scholars who designed the KSS were not phonologists or phoneticians in the way we define these fields today. They were trained in the contemporary Chinese philological and phonological system. Some "mistakes" or poetic segments of a text may shed light on colloquial Khitan, but such conclusions can only be drawn with great caution.

The only reasonable way to describe the KSS is to devise the rules for how Khitan scholars used KSS glyphs for identifying syllables and sounds of the contemporary Khitan reading style.

In this paper we will investigate how the Khitan Small Script makes use of labial stop consonants in the initial position of words and syllables.

Glyphs beginning in the Romanisations with $\left\langle\mathbf{b}>-\right.$ are the following ${ }^{5}:<b>$ 丹 $(311)^{6},<$ bai $>$ 可 $(061)^{7},<$ bai $_{2}>$ 寸 $(060)^{8},<$ bi $>$ 付 $(225)^{9},<$ bir $>4(288)^{10}$, $<$ bod $>$ 田 $(309)^{11},<$ bot> 外 $(176)^{12},<$ bu $>$ 全 $(196)^{13},<$ búl $>$ 外 $(272)^{14}$.

\footnotetext{
${ }^{1}$ The authors are indebted to the anonymous reviewers.

${ }^{2}$ An Epitaph of Prince of Guangling of Great Khitan (Guang 广). See the inscriptions and their Sigla in the Appendix.

${ }^{3}$ An Epitaph of General Xianwu Baligong (Xian 显).

${ }^{4}$ We do not know yet whether the texts were read silently or aloud.

${ }^{5}$ Earlier different readings are here noted as $\mathrm{K}=$ Kane (2009), WJ $=\mathrm{Wu}$ and Janhunen (2010), $\mathrm{C}=$ Chinggeltei (2002), A = Aisin Gioro (2012).

${ }^{6} \mathrm{C}<\mathrm{p}>$

${ }^{7} \mathrm{~K}<\mathrm{ke}^{?}>$

${ }^{8} \mathrm{~K}<\mathrm{ke}^{?}>$

${ }^{9} \mathrm{C}<\mathrm{p}>$

${ }^{10}$ WJ, $\mathrm{K}<$ bun $>, \mathrm{C}<$ pən $>$, A $<$ bur $>$

${ }^{11}$ WJ $<$ hó $>, \mathrm{K}<$ hó $>, \mathrm{A}<$ bə $>$

${ }^{12} \mathrm{C}<$ buo $>, \mathrm{K}, \mathrm{WJ}, \mathrm{A}<$ bu $>,<$ bú $>$, Index $<$ bot $>$

${ }^{13} \mathrm{WJ}, \mathrm{K}<\mathrm{bu}>, \mathrm{C}<\mathrm{pu}>, \mathrm{A}<\mathrm{bu} / \mathrm{abu}>$

${ }^{14} \mathrm{WJ}, \mathrm{K}<\mathrm{bu}_{2}>, \mathrm{C}<\mathrm{pul}>, \mathrm{A}<\mathrm{bu}$, bur $>$
} 
Glyphs beginning in the Romanisations with $<\mathrm{p}>$ - are the following: $\langle\mathrm{p}>$ 业 $(295)^{15},<$ pen> 汁 $(449)^{16},<$ po $>$ 非 $(279)^{17},<$ poy $>$ 墨 $(360=295+071)^{18},<\mathrm{pu}>$ 今 $(241)^{19},<\mathrm{fu}>$ 分 $(242)^{20}$.

Earlier we had also <pú> 斗 (297) which has now to be read as <gú>. The group (297.131) 出及 occurs as a part of the name of a person in the recently found Epitaph of Xiao Chala Xianggong 蕭查刺相公墓誌銘 in Khitan Small Script (AD 1113, Cha), which corresponds to the name Kuyu 骨欲 in the Chinese version of the same epitaph. The pronunciation of 骨 $k u$ and 欲 $y u$ are LMCh $k u t$, EMCh $k w \partial t$ and LMCh jywk, EMCh juwk, ${ }^{21}$ respectively. The final of the first part/-t/ became a fricative and was realised by foreign transcriptions as $/ \mathrm{r} /$ and later disappeared. As to the second part 欲, the final was, according to Pulleyblank, $-y w k$ and $-u w k$. Both had a labial diphthong /uo/ or /uu/ and a final $-k$. This $-k$ disappeared, but in Khitan it had three different traces: $<-\mathrm{h}>(=\gamma)$, diphthong or in special cases zero, consequently 欲 had to be read as *yuo or *yuu or *yuh (yug). The pronunciation of the name is then * Guyug or *Kuyug or *Guyuo or the like ${ }^{22}$. In any case, 斗 (297) has to be read $<$ gú $>$.

As we can see, $<$ bai $>$ 可 (061) and $<$ bai $_{2}>$ 寸 (060), < bot $>$ 外 (176) and $<$ búl $>$ \&l (272), respectively, are alloglyphs or variants.

Interesting is $<\mathrm{bi}>$ 付 (225), which may consist of $<$ bai $>$ on the right side and a diacritic sign on the left, which occurs in a series of other glyphs, see Table 1 below.

Table 1. Glyphs with the same element at the left side

\begin{tabular}{|l|c|l|}
\hline No. & Glyph & Romanisation \\
\hline 220 & 行 & mú \\
\hline 221 & 仗 & $\tilde{\mathrm{n}}^{\mathrm{x}}$ \\
\hline 222 & 伏 & $\tilde{\mathrm{n}}^{\mathrm{o}}$ \\
\hline 223 & 仕 & $\mathrm{mu}^{\mathrm{x}}$ \\
\hline 224 & 任 & $\mathrm{mu}$ \\
\hline 224.1 & 供 & unknown \\
\hline 225 & 付 & $\mathrm{bi}$ \\
\hline 226 & 伴 & $\ddot{\mathrm{u}}$ \\
\hline 227 & 敒 & unknown \\
\hline
\end{tabular}

${ }^{15} \mathrm{C}<\mathrm{p}, \mathrm{f}>$

${ }^{16} \mathrm{WJ}$ has $(438)<$ fen $>$, renumbered and corrected by Wu to $(449)<$ pen $>$

${ }^{17} \mathrm{C}<\mathrm{p}^{6} \mathrm{o}>$

${ }^{18} \mathrm{C}<$ fay, $\mathrm{p}^{6}$ ang $>$

${ }^{19} \mathrm{C}<\mathrm{fu}, \mathrm{p}^{\mathrm{c} u}>$

${ }^{20} \mathrm{C}<\mathrm{fu}, \mathrm{p}^{\mathrm{c}} \mathrm{u}>$

${ }^{21}$ The Late Middle Chinese (LMCh) and the Early Middle Chinese (EMCh) data are quoted from Pulleyblank (1991).

${ }^{22}$ We are not dealing here with the possible etymologies of this name. 


\begin{tabular}{|l|c|l|}
\hline No. & Glyph & Romanisation \\
\hline 228 & 亿 & lú \\
\hline 229 & 仍 & ta \\
\hline 230 & 仅 & unknown \\
\hline 231 & 仅 & unknown \\
\hline 232 & 仅 & unknown \\
\hline 233 & 伔 & kú \\
\hline 234 & 仍 & ta $_{2}$ \\
\hline 235 & 亿 & ri \\
\hline 236 & 化 & ur \\
\hline 237 & 仃 & du \\
\hline 238 & 伊 & BORN \\
\hline
\end{tabular}

The following glyphs also have an element common with others: $<$ bot $>$ 夕ا (176) and $<$ búl $>^{23}$ \&l (272), they may also be alloglyphs with a vertical stroke on the right side. The sign left to the stroke is in case of (272): メ (271) which remained yet undeciphered by the former authors. It occurs four times as initial in Index. The same stroke appears in (058): 朴 $<\mathrm{mi}>,(150)$ 孔 $<\mathrm{ja}>$, (151) 列 $<\mathrm{hu}>,(177)$ 剂 $<\mathrm{ra}>$ or $<\mathrm{us}>$, $<$ uldž $>^{24}$ and (190) 约 $<$ á $>$. In case of the last one it is a clear additional sign to (189) 为 $<\mathrm{a}>$. We will discuss this feature in another paper.

In the case of glyphs beginning with $<\mathrm{p}>$ - interesting may be $<$ poy $>$ 墨 consisting of two glyphs $(360=295 \boldsymbol{\mu}+071$ 黑), one of the rare ligatures in the system.

Important is that $<\mathrm{pu}>$ 分 $(241)$ and $<\mathrm{fu}>$ 尔 (242) differ only by a dot on which see Róna-Tas (2016: 125 and the earlier literature there). The labiodental /f/ was not part of the Khitan system, but in some cases they used $<\mathrm{f}>$ in transcriptions of Chinese. The dotted variant occurs in the following inscriptions: $\mathrm{Yu}^{25}$ (AD 1072), Zhi (1094), Qing (1095), Pu (1105), Zhong (1150) and Nu (1099). In all of those inscriptions, except $\mathrm{Pu}$ (1105), we find dotted and not dotted variants of the same glyph $(241,242)$. Maybe in such cases the absence of the dot was simply due to negligence. As we see, dotting was used for almost a hundred years, therefore we cannot suppose a chronological reason behind this usage. It is more probable that some masters used it, some did not. In other cases Chinese /f/ was transcribed by $<\mathrm{p}>,<\mathrm{pV}>$ etc.

According to Svantesson et al. (2005: 12), in Mongolic the consonants are in a twofold opposition: one series is voiceless unaspirated, the other is voiceless postaspirated in initial position. This is a valid statement for most of the recent Mongol languages, and may be accepted also for Old Mongolian (Svantesson et al. 2005: 198). Phonologically speaking this is an opposition $/ \mathrm{p} /: / \mathrm{p}^{\mathrm{c}} / \mathrm{,} / \mathrm{t} /: / \mathrm{t}^{6} /$ or in another transcription

${ }^{23}$ Reading of Wu Yingzhe in Index instead of $<\mathrm{bu}_{2}>$.

${ }^{24}$ Kane (2009) reads $<$ ra $>$ with ?, Aisin (2012) <uldž, uldži $>$, and Index $<$ ur $>$.

${ }^{25}$ See the list of the sigla in the Concordance Tables in the Appendix of this paper. 
$/ \mathrm{p} /: / \mathrm{ph} /, \mathrm{t} /: / \mathrm{th} /$ and so on. It may be disturbing that in some scripts ${ }^{26} / \mathrm{p} /$ is graphically represented by $<\mathrm{b}>$ and $/ \mathrm{ph} /$ is represented by $<\mathrm{p}>$, $/ \mathrm{t} /$ by $<\mathrm{d}>$ and $/ \mathrm{th} /$ by $<\mathrm{t}>$ etc. The opposition will be of cardinal importance when we compare it to a system which had a threefold opposition, as Middle Chinese had. Baxter $(1992: 46,49)$ gives the following table:

\section{Table 2. Middle Chinese oppositions}

\begin{tabular}{|l|l|l|}
\hline Baxter & Karlgren & Pulleyblank \\
\hline p-, $\mathrm{t}-$ & $\mathrm{p}-, \mathrm{t}-$ & $\mathrm{p}-, \mathrm{t}-$ \\
\hline ph-, th- & $\mathrm{p}^{\prime}-, \mathrm{t}^{\prime}-$ & $\mathrm{p} '-, \mathrm{t}^{\prime}-{ }^{27}$ \\
\hline $\mathrm{b}-, \mathrm{d}-$ & $\mathrm{b}^{\prime}-, \mathrm{d}^{\prime}-$ & $\mathrm{b}-, \mathrm{d}-$ \\
\hline
\end{tabular}

There occurred a labiodentalisation, that is, "Early Middle Chinese labials became labiodentals when followed by medial $-\mathrm{j}$ - and a back vowel (-i-, -u-, -a- or -o-)" (Baxter 1992: 47). Now for the time being we will put aside the labiodentalising feature, that is, all initials which are pertaining to the category labials + medial $-\mathrm{j}-+$ back vowel. To them we will come back later.

\section{$<B>$ in Word and Syllable Initial Position}

Let us now see the correspondences of the Khitan glyphs to the Middle Chinese, or more precisely Liao Chinese (LCh) ${ }^{28}$ phonemes.

b: $<$ b $>$; $[<$ bo $>,<$ ba $>]$ 丹 (311) and $<$ bi $>$ 付 (225)

In the transcription of Chinese, $<b>$ is used for the following Chinese initial types:

Table 3. Khitan $<b>$ transcribing Chinese bilabial stops

\begin{tabular}{|c|c|c|c|c|c|c|}
\hline $\begin{array}{l}\text { Romani- } \\
\text { sation }\end{array}$ & Glyph & Chinese & LMCh & EMCh & $\mathrm{LCh}$ & Source \\
\hline$<$ b.ah $>$ & 丹年 (311.197) & $\begin{array}{l}\text { bo 伯 'uncle on the } \\
\text { father's side' }\end{array}$ & pajk & paijkk/pe:jk & par & K256 \\
\hline$<$ b.oh $>$ & 丹王 (311.377) & $\begin{array}{l}\text { bo 博 'a geographic } \\
\text { name, }\end{array}$ & pak & pak & poy & K72 \\
\hline
\end{tabular}

${ }^{26}$ In the Uighur-Mongol, in the Phagspa, in the Arabic and Cyrillic scripts, though there exist a few special cases.

${ }^{27}$ Baxter has rewritten Pulleyblank's ${ }^{-\mathrm{h}}$ as '-.

${ }^{28}$ We use the term Liao Chinese following Kane (2009: 227-264). As we will see, Liao Chinese is in many respects nearer to Early Middle Chinese than to Late Middle Chinese.

${ }^{29}$ In Bozhou 博州. 


\begin{tabular}{|c|c|c|c|c|c|c|}
\hline $\begin{array}{l}\text { Romani- } \\
\text { sation }\end{array}$ & Glyph & Chinese & LMCh & EMCh & $\mathrm{LCh}$ & Source \\
\hline$<$ b.u $>$ & 丹及(311.131) & bao 保 'to protect' & puaw & paw' & $p \bar{u}$ & $\begin{array}{l}\text { DiX20-8, } \\
\text { K256. }\end{array}$ \\
\hline$<\mathrm{b} . \overline{\mathrm{u}}>$ & 丹下 $(311.372)^{30}$ & $b u$ 部 ‘part, section’ & phus̆ & $b s^{\prime}$ & $p \bar{u}$ & K262 \\
\hline$<$ b.üe $>$ & 丹艾 (311.082) & bie 別 'separate & phiat & biat & bie & K72 \\
\hline$<$ b.iau $>$ & 丹当 (311.362) & 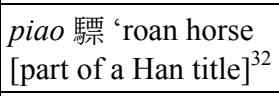 & phjiaw & bjiawh & bjaw & K78, 262 \\
\hline$<$ bi.in $>$ & 付用 (225.303) & $\begin{array}{l}\text { bing 兵 'weapon, } \\
\text { soldier' }\end{array}$ & piajy & piajy & $\overline{p i \eta}$ & K62 \\
\hline$<$ b.in $>$ & 丹雨 (311.018) & $\begin{array}{l}\text { bin 塖 'a place name } \\
\text { in ancient times' }\end{array}$ & pin & pin & pin & Zhon5-52 \\
\hline$<$ b.u.u $>$ & $\begin{array}{l}\text { 丹及そ } \\
(311.131 .131)\end{array}$ & $b u$ 步 'step, pace' & pһй & $b \supset h$ & $b u$ & $\begin{array}{l}\text { Tu10-4, } \\
1123\end{array}$ \\
\hline$<$ b.au.u $>$ & $\begin{array}{l}\text { 丹丸及 } \\
(311.161 .131)\end{array}$ & bao 鲍 'a surname',33 & paw & paiw/pe:w & $b a \bar{u}$ & Xu32-11 \\
\hline
\end{tabular}

A second use of the glyph was in such words where $<\mathrm{b}>$ - occurred in Khitan words. If the initial $b$ - was in the script followed by another consonant, the vowel between $b$ and the next consonant was not always explicitly written, and a vowel had to be read as it would be "inherent", as the vowel /a/ is in the Sanskrit-type alphabets. In most cases the vowel is $/ \mathrm{a} / \mathrm{or} / \mathrm{o} /{ }^{34}$. Let us see a few examples:

- bara'ān 丹布/本斗/为夹 $(311.084 / 393.335 / 189.011),<$ b.ra/ra.ia/a.án> 'right side' $(\mathrm{K} 72,114) \mid$ Mo baragun 'right-hand side, west', Da baren, 'right(hand side)', $\mathrm{DaE} b a r^{y}$ 'id.'. The form $<$ b.ra.ia.an $>$ is occurring only once in $\mathrm{Nu} 14$ in the following example:

$\checkmark \quad$ e.hu iši ayde bara'ian u'úr šari senggün pojuli

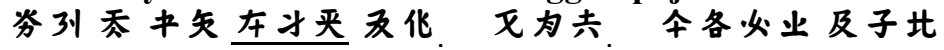

${ }^{30}$ Also < p.u.u $>$ 业及及 $(295.131 .131)$ K262.

${ }^{31}$ In the title biexu.

${ }^{32}$ As it is known LMCh initials with a strong bilabial stop and a voiced aspiration /ph/- may be the continuation of EMCh $p^{h}-j$ - (Departing Tone) and EMCh $b-j$ - (Rising Tone) initial+glide complexes. LCh may have had yet $b-j$ - in this case, and in fact Pulleyblank reconstructed for this word EMCh bjiaw ${ }^{h}$. In this case the j-glide is followed by a high, front /i/. Thus the transcription 丹当 $(311.362)<$ b.iau $>$ is rendering a LCh bjiaw which is nearer to the EMCh than to the LMCh data. We have to add, however, that Khitan did not have a labiodental fricative /f/, on which see below.

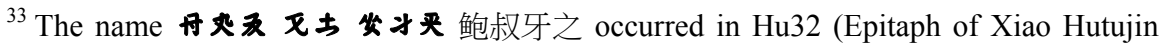
Taishi in Khitan Small Script).

${ }^{34}$ The earlier scholarship read in this word usually $\langle$ bo $>$. There exist $\langle$ b-a $>,<b-i>,<b-0\rangle$ and $\langle\mathrm{b}-\mathrm{u}\rangle$ sequences, see Index. The problem lies in those cases where $\langle\mathrm{b}\rangle$ is followed by $\mathrm{a}$ consonant as $<\mathrm{b}-\mathrm{h}>$ etc. Here the Mongolian cognates and the Chinese transcriptions may help. 
$<$ e.hu ${ }^{35}$ iši ay.de b.ra.ia.an u.úr š.a.ri s.en.ün p.o.ju. $\operatorname{li}_{2}>^{36}$

(033.122.205 109.151311.084.335.011 131. 236028069.175 .273295$.

018.149.076)

'该九 年于右 院 郎君 详稳 除' (《奴》14行)

'(in the) 9th year he was promoted to (the rank of) the Langjun Fieldmarshal (langjun xiangwen) of the Right Division (youyuan)' (Nu14).

Further see $<$ b.ra.ia.ai ${ }_{2}>2 \times,<$ b.ra.iá.ai ${ }_{2} . e n>1 \times$.

Index has 6 times < b.ra.a.an> 丹有为夹 (311.084.189.011), as in:

$\checkmark$ bara'an u'ur süeüen xui yalġa'al oju'un

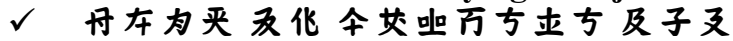

$<$ b.ra.a.an u.ur s.üe.üen x.ui y.al.ha.al o.ju.un>

(311.084.189.011 131.236 244.082.324 340.263 020.098.051. 098 186.149.144)

'右院宣徽迁除' (仲19)

'[he] was promoted to the right yuan (of) Xuanhui' (Zhong19).

$\checkmark \quad$ jurer baqa Diri bara'an u'ur sien ngiu'ui sianggün

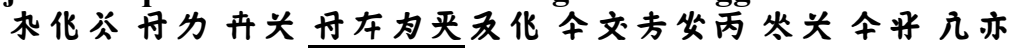

<ci.ur.er ba.qa dir.i b.ra.a.an u.ur s.i.ēn n.iu.ui.i s.ian.g.ün>

(162.236.269 311.168 074.339 311.084.189.011 131.236 244.339.073

264.019.263.339 244.314.334.329)

“次子铁离右院千牛卫将军' (广21)

The second son Diri (was) Right yuan Qianniuwei general (jiangjun) (Hong9).

$\checkmark \quad$ Gem giau Gungbuu Šangšiu bara'an u'ur ling gün uiziang gün temlegey

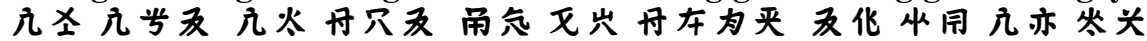
半平儿亦今企夾会万

<g.em g.iau.u g.ụ b.ū.u. ša.ạ š.iu .b.ra.a.an u.ur l.in g.ün ui.i.z.ian g.ün t.em.l.ge.y $>$

$<334.270334 .362 .131334 .345311 .372 .131375 .199028 .289$

311.084.189.011 131.236 261.303 334.329263.339 258.314 334.329.247.257.

261.349.020>

“检校工部尚书右院领 军卫将军封’ (弘9)

'[on] Gemgiau Gungbuu Shangshiu (Jianjiao Gongbu Shangshu) the [title] Right yuan Leading General was conferred' (Hong9).

• *bangg்u- 丹业 3 列 $(311.280 .151)<$.b.áng.hu> ${ }^{38}$ “issue orders ${ }^{39}$. Derivations are: * b áng.hu.al.hu (Liang12)

${ }^{35}<$ e.hu $>$ is a pronoun, may be a demonstrative pronoun.

${ }^{36}$ Glyph (076) was earlier read as $<$ ho $>$ by WJ, $<$ g, $\gamma>$ by C, $<$ ho $>$ by K, $<$ ur, or $>$ by A.

${ }^{37} \mathrm{In}$ this and the following examples we give the context also in cases when we are not sure of the meaning of all words in the phrase.

${ }^{38}$ Shimunek (2014: 113) corrected $(151)<\mathrm{hu}>$ to $\mathrm{y}$ but it should be read as gu. In transciption we retained $<\mathrm{h}>$.

${ }^{39}$ According to Shimunek (2014: 113), this would correspond to Written Mongolian banga'to reprimand'. This is highly dubious. There exists an expression in Khalkha banga xürteex 'to reprimand', but banga is not a verb here, the expression (Mo banga kürtege-) is 'to confer upon somebody banga, to reprimand'. 
A few examples:
b.áng.hu.al.hu.iú (Wu21-16)
b.áng.hu.ai (Lang3-6, Zhong39-29), converbal form
b.áng.hu.ar (Dao17-35, Xuan39-29), past tense
b.ang.hu.u.ji (Song21-13) converbal form

$\checkmark \quad$ bod bangg்ualgu Pusungjien nigu

田业列与列业及午出㜾术公头勺

$<$ bod b.áng.hu.al.hu p.u s.un.ji.en n.i.gu>

(309 311.280.151.098.151 295.131 244.357.152.140 251.339.165)

'身命是 $\square$ 女古' (《梁》12行)

'body was ordered ${ }^{40} \mathrm{Nigu}^{41}$ of Pusungji' (Liang12).

$\checkmark \quad$ RECORDgeen sonlag்u bangġualg̀u'iu Tabuyi Šibsa'amen

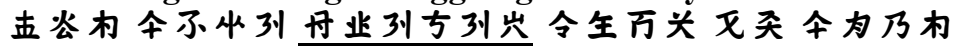

$<$ RECORD.ge.en s.on.1.hu b.áng.hu.al.hu.iú t.abu.y.i sh.ib s.a.am.en>

(052.349.140 244.154.261.151 311.280.151.98.151.289 247.196.020.339

028.127 244.189.184.140)

“撰口命 挞不也十三之' (《匹》21行)

'Record has been issued .... order (of) Tabuye [name of a person] (and) (Xiao)

Shibsam (Shisan) [name of a person]' (Wu21).

$\checkmark \quad$ u'un temudli bod banggiai gesegete

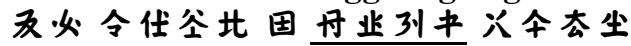

$<$ u.un t.mu.d.li bod b.áng.hu.ai h.s.ge.te ${ }_{2}>$

(131.273 247.224.254.080309 311.280.151.122 340.244.112.356)

' $\square \square$ 身命 $\square$ '《仲》39行)

'body having ordered.....' (Zhong39).

$\checkmark \quad$ Li Ceuen naider bangg்uai šideujid saqo SMALLgaalir

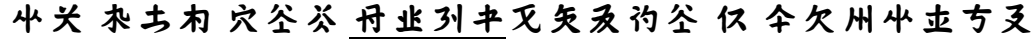

$<$ l.i ci.eu.en nai.d.er ${ }^{42}$ b.áng.hu.ai š.de.u.ji.d ${ }^{43}$ s.qó.SMALLl.ha.al.ir>

(261.339 162.067.140 332.254.341 311.280.151.122 028.205.131.337.254 227

244.169.188.261.051.098.144)

“醴 州之诸官 鸠工修饰” (《郎》3 行)

'officials in Li Zhou have gathered/ordered the craftsmen to repair something (Lang3), 44 .

$\checkmark \quad$ tur bangg்uar tabualga'alguan

今厽业列去全方立列夹

$<$ t.úr b.áng.hu.ar t.abu.al.ha.al.hu.an>

\footnotetext{
${ }^{40}$ Personal order was given? We interpreted 业列キ as 'order' according to 《郎》Lang3, but it does not look so proper in the above examples. It may have some problems.

${ }^{41}$ Nüzhen, Jurchen, an ancient nationality in China

${ }^{42}<$ nai.d.er $>$ is instrumental case. "By the officials an order was given to the XXXcraftsmen." This may point to ergativity: not "he does" but "by him done".

${ }^{43}<$ š.de.u.ji.d $>$ is one word. If this is not a mistake, the earlier reading as $<$ š.de u.ji.d $>$ and the connection between $<$ ujid $>$ and Mo uran, urci has to be abandoned.

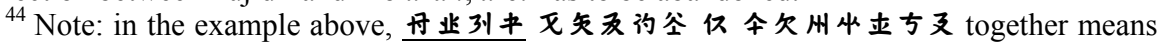
‘扸工修饰”, but we are not sure about the exact meaning of each word.
} 


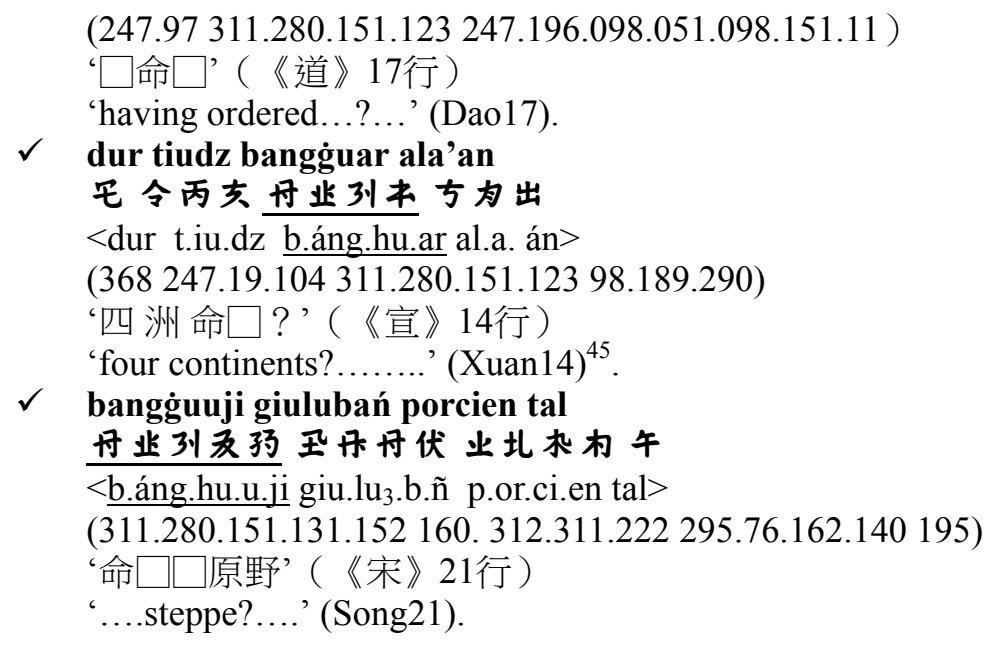

- bas 丹冬 (311.174) < b.as> 'again' (K32, 72, 84, DiX6-5, 19-18, 21-6 33-6, 3518, 40-18, Xiang11-10, 27-12, 32-38, 33-10, 37-26, 44-18, Index 104×). || 冬 (174) may here denote [as] or [asa] | Mo basa, Da base, DaE bas 'again, also'.

Examples:

$\checkmark \quad$ emen lešeu dordei bas pemu

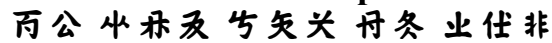

$<$ em.n l.she.u dor.de.i b.as p.mu>

(21.251 261.315.131 218.205.339 311.174 295.224.282)

'女之哀礼从又余' ( 《敌》35行)

'more than mourning etiquette of women....' (Di35).

$\checkmark \quad$ ug̉uli ńour taquši bas ša'ang seše günen iri temlegey

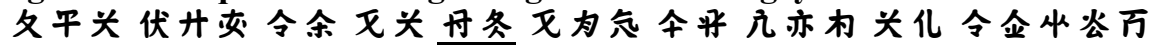
<uh.ul.i ń.ó.úr t.qu š.i b.as ša.ang s.še g.ün.en i.ri t. tem 2 l.ge.y> (172.366.339 222.90.097 247.246 028.339 311.174 028.189.199 244.314

334.329.140 339.235 247.257.261.349.020)

于骨里部都使又上将军之号封 (《图》10行)

'(him) was given the title Governor General (dushi) and also (the title) Top General (shang jiang jun ) of the Uguli (Yuguli) Clan' (Tu10).

$\checkmark \quad$ ongon iris bas temlegelir

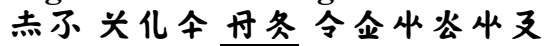

$<$ ong.on i.ri.s b.as t.em 2 l.ge.l.ir ${ }_{2}>$

(71.154 339.235.244 311.174 247.257.261.349.261.144)

‘王之号又封' (《迪》4行)

'(was) promoted to the title Wang again' (Di4).

${ }^{45}$ Note: the meaning of 今丙方 here is a guess, as we are not certain whether the concept of four continents already existed at that time. 
- baqa 丹カ $(311.168)<$ b.qa> 'child' (K72, 118, DiX13-11, 15-20, 26-7, 26-16, 16-24, Xiang 8-4, passim, 48 times in Wu 2012, Index 438×) | Mo baga 'young, childhood', bagačud 'youth', Da bage 'little, young', bage.cude 'youth, young men', DaE -- $\|$ The vowel after $\langle\mathrm{b}\rangle$ may be either [a] or [o], the word was earlier read as boqo, only Chinggeltei read bara. The second syllable appears in ńoqa 伏办 (222.168) <ń.qa> 'dog', Liao shi niehe 捏褐 and in teqa'a 今カ为 (247.168.189) $<$ te.qa.a> 'chicken'. Orthographic variants are: 丹欠 $(311.169)<$ b.qó $>($ Index 1×), $<$ b.qó.a > $(1 \times)$, see also <b.qó.i.ń> $(1 \times),<$ b.qó.du $2 . i>(1 \times)$.

* baǵuan 丹 31 出 $(311.151 .290)<$ b.hu.án> 'children' (Index 187×), also: $<$ b.qo.án> (311.168.290) (Hai6-14) plural,

* baqayi 丹力

* baqa-yi baqa 丹カ头丹カ $(311.168 .339 .311 .168)<$ b.qa.i b.qa> 'grandchild' (K100)| Mo baga-yin baga,

* baqa-yi baǵuan 丹カ头 丹列出 $(311.168 .339 .311 .151 .290)<$ b.qa.i ba.hu.án> 'grandchildren' (Xiang13-11),

jürer baqayi pinde 机化炎丹头业雨矢

(162.236. 347.311.168.339 295.018.205)

$<$ ci.ur.oi b.qa.i p.in.de>

“次子之品于' 《详》17行

'at the "pin" 46 " of the second son' (Xiang17-1),

$\checkmark \quad$ ayden baqai emen bu'úr a’algaai

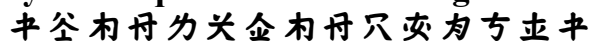

(122.254.240 311.168.339.257.140.311.372.097.189.098.051.122)

<ai.d.en b.qa.i em.en b.ū.ur a.al.ha.ai>

'男孩子之城 $\square \square$ 《详》23'行

'let make (a'alyai) the territory (em) of the children (baqa) of the fathers (ayid-en) permanent (bū'ur) (estate)' (Xiang23-31) ${ }^{47}$.

* baqade 丹力矢 $(311.168 .205)<$ b.qa.de $>$ Dative-Locative case, Index $4 \times$, see further: $<$ b.qa.de.i $>$, <b.qa.d.b.te $>$, <b.qa.iú> $(4 \times),<$ b.qa.iú.i $>$.

$\checkmark$ bu- 丹及 $(311.131)<$ b.u ${ }^{48}>$ 'copula, to be' (K156) (Index 29×)| LMo bol- 'to become, to change into, to be, to exist', Da bole-, DaE bol- 'to become, is, happens to be' in the Central Mongolian languages the verb has a long vowel. The copula occurs in DiX four times, in Wu (2012) 11 times as $<$ p.u $>$, further in $\mathrm{Hu} 6 \times$, Jue $1 \times$. Hui $3 \times, \mathrm{Pu} 1 \times$ and twice as $<$ b.u $>$ (Jue). See perhaps also <búl $>$ 外 (272) below. Orthographical variants are: 丹欠 $(311.372)<$ b.ú> $(6 \times)$, 丹及 $(311.131 .131)<$ b.u.u $>$ $(3 \times)$, 止及 $(295.131)<$ p.u $>(64 \times)$. See also <b.u.úr $>(8 \times),<$ b.u.ji $>$, $<$ b.ú.úr $>(7 \times),<$ b.ú.u> .

bu’ur 丹六交 $(311.372 .097)<$ b.ū.úr> 'permanent, what existed and exists' (Xiang23-17, Xiang23-34), past tense. Index (7×). Orthographical variants

\footnotetext{
${ }^{46}$ pin is a Chinese territorial unit, cf. $<$ po-ho p.in>, <p.a.ai p.in $>$ K 191, Note 16.

${ }^{47}$ Whether ₹爸朮 denotes “fathers" or “men" is not yet clear.

${ }^{48}$ The copula may also be read as bau- or bou-.
} 
are: 丹及玄 $(311.131 .097)<$ b.u.úr> (Index 8×) (Xiang15-16, 17-18, 20-5, 22-21), 丹多化 $(311.131 .236)<$ b.u.ur $>(1 \times)$.

Written with $\quad$ < $<$ bul $>(279)$ :

* bular 4 邚为 $\neq<$ búl.a.ar> (272.189.123) 'was, existed' (Jue38-29)

$\checkmark \quad$ tir buludu ojugai bula'ar

今刃邚及尼及子赤中外为中

$<$ t.ir búl.ú.dú o.ju.ha.ai búl.a.ar>

(247.137 272.131.073 186.149.051.122 272.189.123) (Jue27-29) ${ }^{49}$.

bayi- 可 $(061)<$ bai $>$, 寸 $(060),<$ bai $_{2}>$. According to Kane (K40-41) 寸 (060) is an allograph of (061), and considered its reading of (061) as uncertain. SJL followed him. WJ read both glyphs as <bai $>$ and Jiruhe and Wu (2009, cited by WJ p.48) suggested to eliminate (060) at all, and replace it by (061). We accept this and read $<$ bai $>$. Index has only the glyph 可 $(061)<$ bai $>31 \times$. The glyph occurs in:

bayi- 可 (061) < bai ${ }_{2}>$, 'to stand still, stop' (K42, DiX31-21) | Mo bayi- 'to be, to stay, to exist', Da bai- 'to exist, be (it is), stand, stand up, stay, stop, give up', DaE bai-, while as auxiliary the Mongol word got another shape (vai-, vi-, $i-$, see HN 277), Index $31 \times$. Derivated forms are:

*bayid- 可爸 $(061.254)<$ bai.d $>$ the passive form of bayi- in:

- bayider 可公公 $(061.254 .341)<$ bai.d.er $>$ past tense of the passive stem, Index $1 \times$.

*bayidga- 可全亚 (061.254.051) the factitive form in - $\dot{\mathrm{g} a}$, of the passive stem bayid- in:

* bayidga'ai 可爸走 ₹ (061.254. 051.122) < bai.d.ha.ai> (DiX31-9) (a converb in -ai, of a factitive form in -ga), $(14 \times)$,

* bayidga'ar 可全走 $(061.254 .051 .123)<$ bai.d.ha.ar> $(1 \times)$, past tense of bayidga-,

* bayidġa'a'ar 可爸来为 $(061.254 .051 .189 .123)<$ bai.d.ha.a.ar> (4×), past tense of bayidga-,

* bayidga'alir 可爸五ち及(061.254.051.098.144) < bai.d.ha.al.ir ${ }_{2}>$ Index 1×,

* bayidga'aju 可兊漛为共 (061.254.051.189.386) Index 1×,

*bayidla- 可爸夾 $(061.254 .261)<$ bai.d.la> a factitive form of the passive stem in:

* bayidlaga'ai 可爸坐正中 (061.254.261.051.122) Index < bai.d.l.ha.ai>,

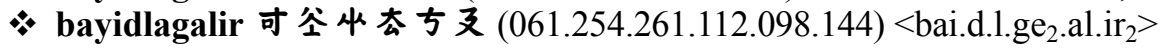
Index $1 \times$,

*bayilga- causative stem,

- *bayilga- 可坐正 <bai.l.ha> (061.261.051) 'to cause to be, remain, to leave, to cause to stop, to dismiss, to remove from office' । Mo bayilga- 'id.'

(with the causative/passive suffix -lga-), Da bai.legaa- 'stand him up, have him stand up'.

${ }^{49}$ The meaning of the phrase is not clear, but see the following expression in Xiang42-17: $<\ldots$..t.ir.bú $2 . u . d u ́$ x.s.ge.ud ja.ri.ha.ar $>$ and in Xiang30-12: <t.ir.bú $2 . u . u i>$, -du in the first example is the suffix of the dative locative. $<$ t.ir.bu $>$ may be a title. 
bayilga'ar 可坐走为 $\neq$ bai.l.ha.a.ar> (061.261.051.189.123) 'was removed (from office)' (DiX38-17) past tense.

There exist glyphs for /bi/ initials. Let us see them:

bi: $<$ bi $>$ 付 (225)

According to Kane (K62) this glyph is used only in transcription of Chinese. As in:

$\checkmark$ bing 付同 $(225.303)<$ bi.ing $>$ 'weapon' $\mid \leftarrow$ Chinese bing 兵 'weapon, soldier', LMCh piajy, EMCh piajy. (K62, see also Jue5-50.) But the glyph occurs also, at least once, in a Khitan word in

$\checkmark$ biduji 付爸及㜾 $(225.254 .131 .152)<$ bi.d.u.ji> '?' (Xiang46-12) ${ }^{50}$.

bir: < bir $>$ 4 (288). This glyph was earlier read as $<$ bun $>$, recently $\mathrm{Wu}$ read in Index $<$ bir $>$. The glyph occurs in

\section{Examples for 歹}

*biru 快 $(288.131)<$ bir.u>:

$\checkmark$ u'ulun'un biru sir u'un tabualġa'alġuan jariqo püeziuu'n

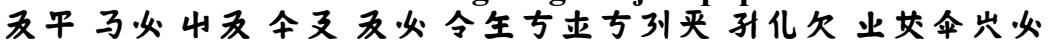

$<$ u.ul ju.un bir.u s.ir 2 u.un t.abu.al.ha.al.hu.an ja.ri.qó p.üe.z.iú.un>

(131.366 147.273 288.131 244.144 131.273 247.196.098.051.098.151.011 150.235.169 295.082.258.289.273)

冬夏 $\square \square \square \square$ 宰相别胥之 (《迪》12行)

'Winter/summer (of) wife of the prime minister in feudal China' (Di12$7 / 15)$

$\checkmark$ colġa'a'ar irien ünen biru pin xarlues gedege'er

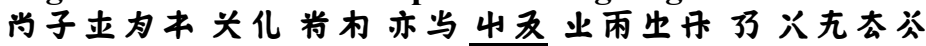

$<$ co.l $1_{2}$.ha.a.ar i.ri.en ün.én bir.u p.in.xar.lu lu $_{3}$ h.d 3 .ge.er $>$

(298.149.051.189.123 339.235 299.140 329.361 288.131 295.018.287.312 $146340.089 .112 .341)$

‘ $\square$ 号 $\square \square \square \square \square$ 未' (《玦》6行)

'... title ... never...' (Jue6)

$\checkmark$ uniqu do 066li ġulalg̀u'iu baqa'i euru

杏余朱土圠年夾列岀出及丹米去化

<uni.qu.do 066.li hul.1.hu.iú bir.u b.qa.i eu.ru>

(059.246.217 066.080 048.261.151.289 288.131 311.168.339 067.236)

‘少于 $\square \square \square$ 子 岁于'(《玦》11行)

'... younger than... son at the age of' (Jue11)

Examples for 4 4 4 凡 $(288.261 .334)<$ birlig $>$ :

$\checkmark$ hoi uru bod birlig taibo pogolir 一及化田出夾凡空丹业及困夹及 $<$ hoi u.ru bod bir.l.g tai.bo p.o.go.l.ir $2>$

(001 131.236 309 288.261.334 374.311 295.186.304.261.144)

'北院护卫 (护身) 太保 除' (《仲》8行) 
'Promoted to (the rank of) Huwei taibao of the North Division (beiyuan)' (Zhong 8)

$\checkmark$ dur ayde bod birlig o'oi 导失田出坐九及态

$<$ dur ai.de bod bir.l.g o.oi>

(368 122.205309288 .261 .334186 .107$)$

“四 年于护卫授' (《蒲》9行)

'Promoted to guard in the fourth year' (Pu 9)

$\checkmark$ te MONTHde tugili bod birlig au'ulġa'ai

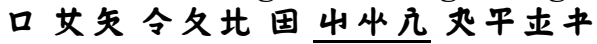

$<$ te MONTH.de t.uh.li bod bir.l.g au.ul.ha.ai>

(323081.205 247.172.080309 288.261.334 161.366.051.122)

“该月于 $\square$ 护卫改” (《显》12行)

'Reassigned as flagged (tugili) guard in this month' (Xian12)

bir 出及 $(288.144)<$ bir.ir $2>$ in:

$\checkmark$ nai nai gende tequ dadusde birir poli

公中元矢分太久丹矢4及业及子头

$<$ nai n.ai.g.én.de t.qú da.dus.de bir.ir p.o.l.i>

$\left(211.2^{51} 251.122 .334 .361 .205247 .118\right.$ 171.310.1.205 288.144 295.186.

149.339)

‘八十 $\square \square \square \square$ 成为' (《胡》24行)

'Eighty become' (Hu24)

$\checkmark$ asar šulul bais tiwir birir isuń MR.anji

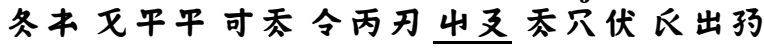

$<$ as.ar š.ul.ul bai.is t.iu.ir bir.ir is.û.ñ MR.án.ji>

(174.123 028.366.366 061.033 247.019.137 288.144 033.372.222 170.290.

152)

‘清 $\square \square$ 康 $\square \square \square$ '(《仁》22行)

'A peaceful....was virtue Kang' (Ren22)

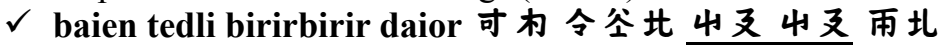

$<$ bai.en t.d.li bir.ir bir.ir dai.or $>$

(061.140 247.254.80 288.144 288.144 17.76)

“朝 $\square \square \square$ 下' (《宣》16行)

'Morning down' (Xuan16).

* *birgis 4 亿午 $(288.334 .244)<$ bir.g.s $>$ (Xiang24-19) where $<$ s $>$ seems to be a plural marker. See further: Index $<$ bir.li $i_{2} . i>$. Further examples are $<$ bir.u.ji $>,<$ bir.u.ur.ir $r_{2}>$.

- bod or bud: $<$ bod $>$ 田 (309). This glyph was earlier read as $<$ hó $>$, recently Wu Yinzhe (Index) identified it as $<$ bod $>$ and he tentatively translated it as

${ }^{51}$ A newly identified glyph. 
'he', the 3 rd person pronoun. As an isolated word it is frequent. In the Index it occurs $116 \times{ }^{52}$

The reason for this change is the following:

It can be observed that there are several ways to write Nabo 捺钵 'travelling camp, settlement' in Khitan, such as 公东全东<n.ad.bu.ad> (Gu3), 公东全东龹 $<$ n.ad.bu.ad.i $>$ (Xing2), 公东全企头 $<$ n.ad.bu.d.i $>$ (Xuan5), etc. We hold that 马必 公可. 田 < ju 2 .un n.ad. bod $>$ in Xian15 and Xian16 perhaps denotes Xia Nabo 夏捺钵 (summer Nabo). Thus, 公东田<n.ad.bod $>$ and 公东生东 $<$ n.ad.bu.ad $>$ share same meaning and pronunciation, and therefore 田 and 全东 have to have the same pronunciation. We already know that 全 has to be read as $<$ bu abu $>$ and 5. as $<$ ad $>$. So in this case 田 reads $<$ bud $>$. Further, in 今冬田 (247.174.309) and 今冬丹全 (247.174. 311.254) 田 and 丹爷 < b.d > also seems to be used alternatively. Therefore, we can infer that $⿴ 囗 十$ can be read as $<$ bod $>$ or rather $<$ bud $>$.

Examples for $<$ n.ad.bu.d $>$ 公东生打. (251.099.196.099) $2 \times$ :

$\checkmark$ Muji nadbud emuseg 任及肠公东生东无全九

$<$ mu.u.ji n.ad.bu.ad emu.s.g $>$

(224.131.152 251.099.196.099 026.244.334)

'圣捺钵（或宗室）统一?' (《故》3行)

'Sacred Nabo [temporary imperial palace or imperial clan] unify?' (Gu3)

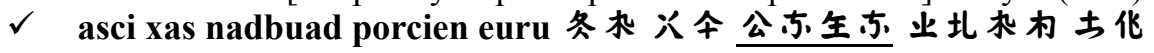

$<$ As.ci x.s n.ad.abu.ad p.or.ci.en eu.ru>

(174.162 340.244 251.099.196.099 295.076.162.140 067.236)

' $\square \square$ 捺钵 $\square$ 岁于' (《弘》24行)

‘... Nabo [temporary imperial palace]... at the age of...' (Hong 24).

$\checkmark$ HEAVEN udulga'a'ar hongdi meren nadbuadi del ör semuen udu'udu sa'ai öliuer

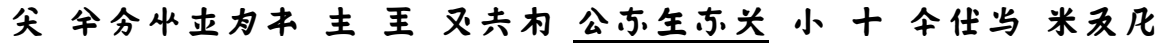
羊为中夹丙丹公

$<$ HEAVEN ú.dû.l.ha.a.ar hong di m.ri.en n.ad.abu.ad.i del ör s.mu.én udu.u.dú s.a.ai l.iu.ir.er>

(243 245.249.261.051.189.123075037 133.069.140 251.099.196.099.339294

040244.224 .361355 .131 .179244 .189 .122 261.019.137.341

“重熙 $\square$ 皇帝捺钵之南西行宫于 驻跸 崩' (《兴》2行)

'Emperor Chongxi ... died when he resided (sa.a.ai) at the southwest residence (emperor's stop over place during journey) of Nabo (temporary imperial palace)' (Xing2).

$\checkmark \quad$ süeüen ii neue em eusuir ġuoren nadbudi öliuren

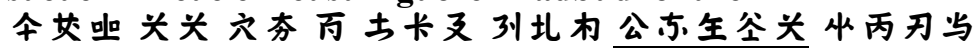

$<$ s.üe.üen i.i neu.e em eu.su.ir 2 hu.or.en n.ad.abu.d.i l.iu.ir.én>

(244.082.324 339.339 331.109021 067.41.144 151.076.140251.099.196.254. $339261.19 .137 .361)$

${ }^{52}$ In line 3 of the Khüis Tolgoi inscription (unpublished, forthcoming by Maue et al.) there occurs a word read bodi and translated by Vovin as 'tribe'. We have not made any research on the Khüis Tolgoi inscription yet, so we cannot make a comment on it. 


\section{“宣 懿皇后长庆川之 捺钵于 崩’(《宣》5行)}

'Empress Xuanyi ... at the Nabo [temporary imperial palace] of/in Changqingchuan [place name]...died' (Xuan5).

Examples for $<$ n.ad.bot $>$ 公东外 (251.099.176), Index 25×:

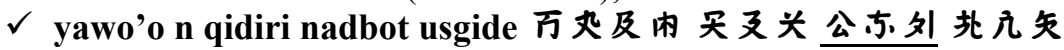

$<$ y.au.o.ón qid.ir 2 .i n.ad.bot us.g.de $>$

(020.161.186.322 365.144.339 251.099.176 068.334.205)

“道 契丹之捺钵（或宗室）字于’(《显》6行)

'in the letters of the Nabo (temporary imperial palace) (or imperial clan) of Khitan' (Xian6). ${ }^{53}$

$\checkmark$ yarudi nadbot guas ugar 万布及火头公可外列冬父中

$<$ y.ri $i_{6}$.u.ud.i n.ad.bot hu.as uh.ar>

(020.084.131.344.339 251.099.176 151.174 172.123)

‘耶律 宗室 $\square \square$ ' (《兴》7行)

'The Nabo of the Ye lü [the surname Yarud] imperial clan....' (Xing7)

\section{$\checkmark$ HEAVEN GOLD hongdi ca nadboten išien uń} 䏌山主王角先公方外枟与及伏

$<$ HEAVEN GOLD hong di ca n.ad.bot.en iši.én 2 .u.ñ $>$

(243286075037375.203 251.099.176.140 33 100.131.222)

'天 金? 皇帝 $\square$ 捺钵之九帐' (《玦》3行)

'Heaven gold? emperor nine palaces of Nabo' (Jue 3)

At present we cannot answer all questions about the glyph 田. The pronunciation has to be further studied in the future.

We find in the Index: $<$ bod.l.b.ń.de.i $>,<$ bod.l.b.ń.er $>$. If it is declined, we find: $<$ bod.d $>$, < bod.de $>$, < bod.en $>$.

bot 外 (176). This glyph was earlier read as $<$ bú $>$, Index has $<$ bú $>$, recently Wu read $<$ bot $>$, later $<$ bod $>$ see above. It occurs also in:

- botud 外爸 (176.254) <bot.d> 'other' (DiX1-1/2, 2-3, Xiang1-12, 16-14 Index $26 \times)$. The glyph was earlier read also as $<$ bu.d $>$. It occurs together with naġaner 力啬出 $(139.051 .290 .341)<$ na.ha.an.er> the 'maternal uncles', that is the "other clan", as <bod.d na.ha.an.er $>$ the Xiao clan, that of the maternal uncles, practically the Uyghurs | The Khitan word may pertain to an Ancient Mongolic *bu/bo stem. This appears in Mongolic busu a plural in $-s$, which was petrified later and got a second plural $-d$ : busud. The Khitan form bodud or budud would be then structurally the same as Mongolic busud, a plural in $-d$ of a petrified former plural *bud.

${ }^{53}$ Note: since the examples given here are extracted from certain lines in the inscriptions where most of the content of some lines is yet to be deciphered, we know the meaning of some words when seperately written, but we are not sure about the meaning in the context. For some cases, we are uncertain whether they belong to the same phrase group. For example, 万丸及内(道) and 圤九矢 (字于) in the above case. 
bu: $<$ bu $>$ 全 (196). Wu read 主 (196) as <abu> which may be the correct reading in some initial positions. Some words written with (196):

- abu 全 <abu> (196) 'old man, grandfather ${ }^{54}$.(Index 61×). | Mo. $a b u$ 'father, grandfather'. The glyph 全 <bu> (196) occurs in such expression as:

- abu ay 主平 (196.395) < abu.ay> 'grandfather' at least in the first two cases in Xiang7-33, 19-22,38-33 (in the third the following word is illegible).

- abu abu ay 主全平 (196.196.395) <abu.abu.ay> 'great grandfather' (K100).

The glyph occurs also in word internal position as in 今全万爻 (247.196.020.

269), <t.bu.y.er> which is a name occurring in the Liaoshi as Tabuye 撻不也 and the like ${ }^{55}$. The word tabuyer is also a common word denoting 'a tiller of fields' according to the Jinshi glossary (K59).

Index has the following data:

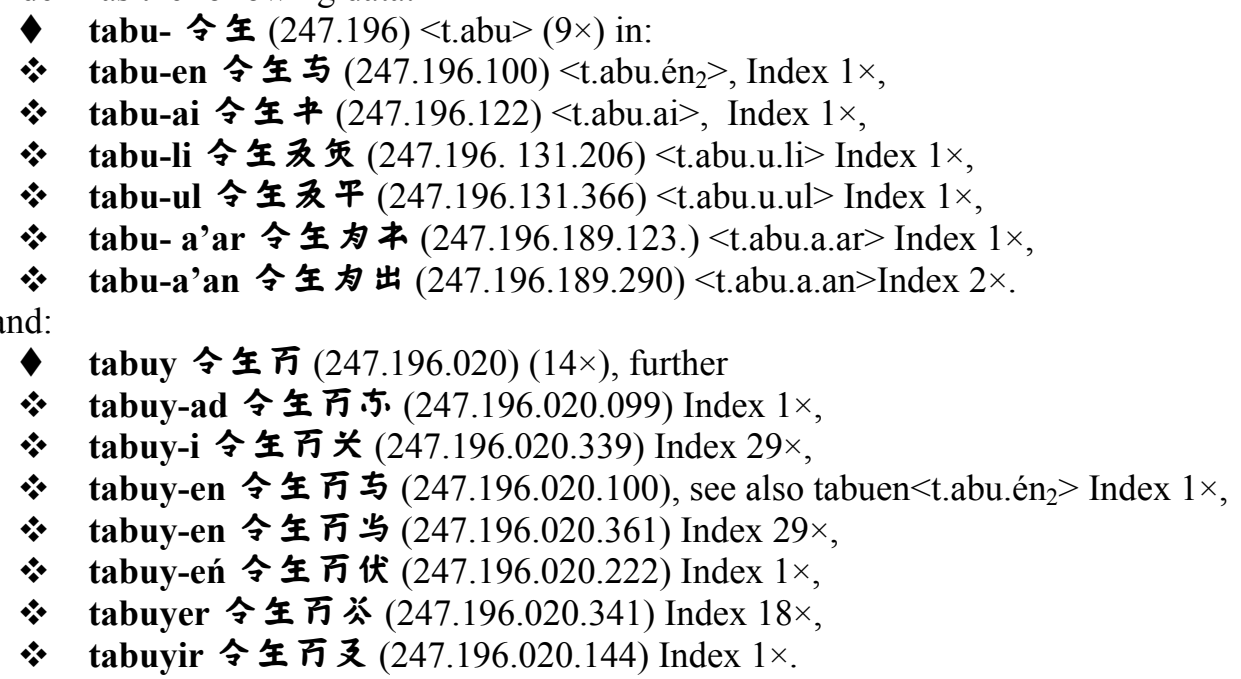

A further derivation may be *tabu(a)l-. In these stems there is no $b \sim p$ alternation, no *tapu occurs.

bul $\$ 1(272)<$ búl $>$. This glyph was earlier read as $<$ bu, bú $>$, it is now read by Wu and Index as $<$ búl $>$. It is occurring in a name:

- Lebulag senggun <le.bul.ah s.ēng.un> Chinese Lubugu xiangwen 魯不古詳 穩 (K68) who figures in the Liao shi. Here <bul $>$ is transcribing Ch $b u$ 不, LMCh put, EMCh put, pat, but the name looks much like a Khitan name (?Elbulag), and should have been transcribed as Lubulgu (魯不勒古), which was then retranscribed into Khitan.

The glyph also occurs in the expression

* buluji 外及约 $(272.131 .337)<$ búl.u.ji $>$ (Xiang35-12) and

\footnotetext{
${ }^{54}$ Róna-Tas read earlier ebü, see Mo ebüge 'ancestor, grandfather', DaE aukə 'elderly man', but the correction of Wu to $a b u$ is a better reading and should be accepted.

${ }^{55}$ WF424 mentions a person of the royal clan with that name, who surrendered to the Jurchen in 1116.
} 
* bula'ar 外为キ<búl.a.ar> (272.189.123) (Jue38-19). Both --ji and -ar are verbal suffixes, the first forms converbs, the second marks the past tense, therefore bul has to be a verb. This verb may be the same as bu-/pu- 步/步 $(311 / 295.131)<$ b/p.u $>$ see above.

Index has also buluń 邚石伏 (272.131.222), bulhu 邚列 (272.151) (3×), bula 外为 (272.189), buli 外头 (272.339).

bir $4 \mathrm{f}<$ bir $>$ (288), the glyph was earlier read as $<$ bun $>$ now it is read by Index and $\mathrm{Wu}$ as $<$ bir>. As we observed the second word 用丹及 in 幽圣为用䑥 米及化更全 <le.ém.hu.a il.bir.ún udu.u.ur hú2.ú> (261.270.151.189 302.311.144 355.131.236 014.245) meaning 林牙夷离毕行宫统 (linya yilibi xinggong tong) in Chinese (DiX10-7-10) denotes Chinese yilibi 夷离毕, and the third word 用 4 in

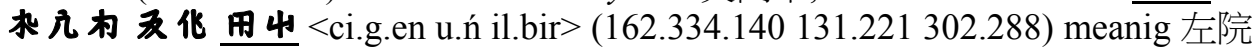
夷离毕 (zuoyuan yilibi) in Chinese, appeared in Guang14 also denotes yilibi 夷离 毕. Thus, we can infer that 用山 and 用丹文 have the same meaning and pronunciation, which can further prove that $\boldsymbol{\psi}$ equals $\boldsymbol{f}^{56}$. If (288) has to be read as $<$ bir $>$ then the title is:

- ilbir 用 出 $(302.288)<$ il.bir> (Index 12×), also 用丹及 $(302.311 .144)<i 1$. b.ir ${ }_{2}>$ 'tribal judge' (DiX10-8), gen. 用山本 $(302.288 .140)<$ il.bir.en $>$ 'tribal judge+gen' (Xiang8-27. 13-13, 18-14, PU16-17 Index 5×). According to $\mathrm{WJ} 79,156 \leftarrow$ Ch yilibi 夷離畢 LMCh *jilipjit. This was first suggested by Sun Bojun and Nie Hongyin (2008) quoted by WJ79, see also Wu17 223, 235 . They suggested as a final source OT el begi. This is problematic. The original may have been $*$ Eliber $^{57}$.

According to Aisin Gioro (2012) the glyph 地 (077) may be read as $<$ bur $>$ or $<$ bor $>$ but we did not find any evidence for this claim. This is an allograph of $t$ t (080) with the value $/ \mathbf{1} /$ and transcribed hitherto by $<\mathrm{ii}>$ thus it does not pertain here (see Róna-Tas 2017: 156).

\section{$<\mathbf{P}>$ in Word and Syllable Initial Position}

\section{p: $<\mathrm{p}>\boldsymbol{\mu}(295)$}

The glyph for the initial $\mathrm{p}$ - is $<\mathrm{p}>\boldsymbol{\mu}$ (295). This glyph used as a word initial is very frequent. It occurs before all vowels. In the transcription of Chinese, the glyph appears in three types of initials.

\footnotetext{
${ }^{56}$ Aisin Gioro Ulhicun (2012) read $\boldsymbol{Z}$ as ir/r, we read $\boldsymbol{\psi}(288)<$ bir $>$. The reconstruction of this pronunciation is not so certain, and needs further examination.

${ }^{57}$ A possible connection with the well-known title elteber will be dealt with in another paper.
} 
Table 4. Khitan initials with $\mathbf{p} / \mathbf{f}-$

\begin{tabular}{|c|c|c|c|c|c|c|}
\hline Romanisation & Glyph & Chinese & LMCh & EMCh & $\mathrm{LCh}$ & Source \\
\hline$<$ p.ing $>$, & 业同(295.303) & $\begin{array}{l}\text { ping 平, 'level, } \\
\text { even, peaceful' }\end{array}$ & phiajy & biajy & $b \bar{i} \eta$ & K70 \\
\hline$<$ p.i $>$. & 止头 (295.339) & $\begin{array}{l}f e i \text { 妃, 'wife, } \\
\text { consort' } 58\end{array}$ & fjyj/fji & phuj & $p i$ & K70 \\
\hline$<\mathrm{pu}>$ & 分 $(241)^{59}$ & $\begin{array}{l}f u \text { 府 'treas- } \\
\text { ury' }\end{array}$ & fjyă/fuð̆ & pŭ̀' & $p u$ & K63 \\
\hline$<$ p.úy $>$ & 止光 (195.357) & $\begin{array}{l}\text { feng 奉 'pre- } \\
\text { sent (to a su- } \\
\text { perior)' }\end{array}$ & $\begin{array}{l}\text { fhjyawy/ } \\
\text { fhay }\end{array}$ & buawy & 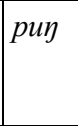 & $\begin{array}{l}\text { K262, } \\
\text { No. } 7.013\end{array}$ \\
\hline <pu.ši.iń>. & \begin{tabular}{|l|} 
今忝伏 \\
$(241.033 .222)$ \\
\end{tabular} & $\begin{array}{l}\text { furen 夫人 } \\
\text { 'lady' }\end{array}$ & fja/fuə & puə & $p u$ & K63 \\
\hline$<$ fu.ong $>$ & 分黑 (242.071), & $\begin{array}{l}\text { fang 防 'ward } \\
\text { off, protect' }\end{array}$ & $\begin{array}{l}\text { fhjyan/ } \\
\text { fhay }\end{array}$ & buay & fuon & \begin{tabular}{|l} 
K262, \\
No. 7.012
\end{tabular} \\
\hline
\end{tabular}

Generally there is no Khitan glyph which would reflect an $f$ - initial. There does exist $<\mathrm{fu}>$ 尔 (242) which is a dotted variant of $<\mathrm{pu}>$ 分 (241). In this case the dot in 分 $<\mathrm{fu}>(242)$ is marking a phonetic peculiarity, existing in Chinese, but not in Khitan ${ }^{60}$. If it which was earlier listed under (438) and now by CWJ as (337.1) has to be read as $<$ pen $>$ and not $<$ fen $>$ as did WJ, then we may state that the Khitan $p>$ f change had begun before the labial $/ \mathrm{u} /$ in Chinese transcriptions.

Chinese loanwords written with $\boldsymbol{\mu}(295)<\mathrm{p}>$ in Khitan include:

paisï 业中/平进 $(295.122 / 395.083)<$ p.ai/ai 2. sì $>$ 'païsï, tablet of order' $\leftarrow$ Ch paizi 牌子, LMCh pha:jtsz EMCh baij/be:j, see WOT99. In:

paisii-en 业キ/平进: 林 $(295.122 / 395.083: 140)<$ p.ai/ai 2. sï.en> gen. of 'paizi' (Nan2, K192), Index 12×,

paisï-de 止进: 矢 $(295.122 .083 .205)<$ p. ai.sï.de $>$ dative-locative.

*paw 业专 $(295.125)<$ p. aū $>^{61}$ 'to die' (K49) $\mid \leftarrow$ ? ? Ch piao 殍 'starve to death, to perish', LMCh phiaw, EMCh biaw ${ }^{62}$.

${ }^{58}$ Also pei.

${ }^{59}$ Written also with $<\mathrm{fu}>$ 分 $(242)$.

${ }^{60}$ There do exist other glyphs which denote sounds not present in Khitan but existing in Chinese: for instance $\bar{\chi}(028)$ is $<\check{\mathbf{s}}>$ and does exist in Khitan, 文 (330) is an alloglyph of $\bar{\chi}(028)$ with a dot above and denotes /ž/ existing only in Chinese. This is a clear parallel to 今 $<\mathrm{pu}>(241)$ and 分 $<\mathrm{fu}>(042)$.

${ }^{61} \mathrm{~K}$ read $<$ ió $>$, WJ read $<\mathrm{au}>$ and Aisin $<$ jau $>$ for (125).

${ }^{62}$ For a semantic parallel, see Khitan ölü- 4 丙 $(261.019)<1$.iu $>$ - 'to die, to pass away (honorific)' (K91) $\leftarrow$ OT öl- 'to die', cf. Mo ölüs- 'to suffer starvation', ölüng 'starvation', ölber-, ölmer- ölmü-r 'to suffer extreme hunger, starve' or ? Mo ükü- 'to die', Da uu-, HN ükü-, DaE ur ${ }^{w}$, $u:-$. The Mongolic Qinghsi-Gansu languages have all * $p$ - (EYu, MgrH, MgrM, Bao, Dgx, only Kgj has $g u$-). According to Hans Nugteren (2011: 540), the * $p$-s are secondary. In MMo only the Rasulid 
* pau-er 止䒓公 < p.aū.er> (295.125.341) 'died' (DiX4-22), (Index 10×), past tense.

Index also has: pau-li 步考比 $(295.125 .080)<$ p.aū.li $>$, pau-en 步去尚 $(295$. 125.361) <p.aū.én>.

$\checkmark$ pin 业雨 $(295.018)<\mathrm{p}$.in> 'a unit of territory', Ch ping 平 LMCh phiajn, EMCh biajp. ${ }^{63}$ (Index $40 \times$ ).

$\checkmark$ pa'ai pin 业为中业雨 $(295.189 .122295 .018)<$ p.a.ai p.in>,

$\checkmark$ poġo pin 非圠业雨 $(279.076$ 295.018) < po.ho p.in> (K191, Xiang14-13),

$\checkmark$ pa'ar pin TWO THOUSAND 业为キ业雨圣矢

(295.189.123 295.018134207$)<$ p.a.ar p.in TWO THOUSAND>,

'two thousand housholds [were given]'.

$\checkmark$ pa'ar pin FIVE THOUSAND 业为キ业雨毛矢

(295.189.123 295.018 029.207) <p.a.ar p.in FIVE THOUSAND>

'five thousand [feudal] housholds [were given]' (K122).

* pinde 业雨矢 $(295.018 .205)<$ p.in.de $>$ locative $($ Index 3×).

curoi baqai pinde 水化炎丹为头雨矢

(162.236.347 311.168.339 295.018.205) <ci.ur.oi b.qa.i p.in.de>

'at the houshold of the second son' (Xiang17-1/3).

- pini 止雨头 $(295.018 .339)<$ p.in.i $>$ genitive $($ Index $7 \times$ ).

Names written with $<\mathrm{p}>\boldsymbol{\mu}$ (295):

十业有及 $<$ p.ra. ir $_{2}>(295.084 .144)$

'拔里'《姑》6 行,

'Bali (*Beitli) name of a Khitan tribe' (Gu6)

- 业余㜾 <p.qu.ji> (295.246.152)

'蒲古只 (人名)' 《抄盖》2 行

'Puguzhi (name of a person)' (Chao Gai2)

Some Khitan words beginning with p-:

- $\operatorname{par}^{1}$ 业布/本 $(295.084 / 397)<\mathrm{p} . \mathrm{ra} / \mathrm{ra}^{0}>$ 'ten'। MMo harban, Mo arban 'ten', see Róna-Tas (2016: 129-132), Index 9×,

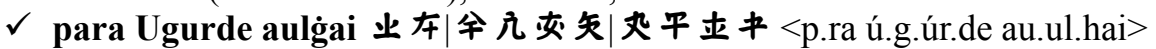
(DiX32-11-14) '[the Emperor] let [him to be] appointed to the Ten Ugurs'.

Also Hu39-15: <t.mu.t.ii p.ar>.

- $\operatorname{par}^{2}$ 业ћ $(295.123)<$ p.ar $>$ in:

$\checkmark$ mot/d par 百令/空业キ<<mó.t/d p.ar> 'wife' (K126, DiX12-13, 25-25,

Xiang7-21, 12-29, 16-7) $\|$ perhaps a count word, see Róna-Tas (2016: 132).

- pō 业及(及) (295.186.186) <p.o, p.o.o> 'monkey' (K107), <po'o> (C107) | cf. Mo bečin, Da monioo, Ma bonio, monio (Index $5 \times$ ).

Hexaglott (ed. Golden 2000) has one datum with $h$ - : hüküdel 'grave', but ükü- to die',? cf. Mo ügei bol- 'to die'. The etymology is uncertain.

${ }^{63}$ It is remarkable that $(018)$ and an alloglyph (454) are read with final $<-\mathrm{n}>$, and not $<-$ ng>. May be Khitan did not have this final, see Kane (2009: 71). 

$\checkmark$ par MONTH liauqu po orlabir taw DAY WHITE 216.gंu yeurugey

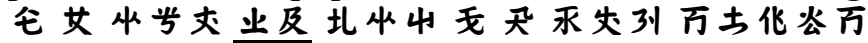 (240 081 261.362.118 295.186 076.261.288 029 159007. 216.151020 .067$. 236.349.020)
<par MONTH 1.iau.qú p.o or.1.bir tau DAY WHITE 216.hu y.eu.ru.ge.y> ‘十月丙申朔五日庚子迁' (《太》4行)
'Promoted in the tenth month, the red (坐岇丈<l.iau.qu $>$ ) monkey (业及

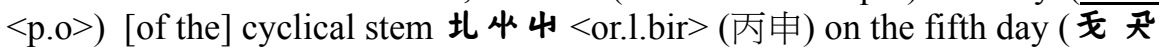 $<$ tau DAY $>$ ) of the WHITE X.hu cyclical branch (庚子) $<$ y.eu.ru.ge.y $>$ [i.e. on the 5 th October]' ${ }^{64}$ (Tai4).

Note: 承灾列 is $<$ WHITE.216.hu $>$ where 头 (216) must be a Khitan name of the cyclical branch and $33_{1}<$.hu $>$ is an adjectiviser as -qú in $<1$.iau.qú $>$. 'The 10th month was "red monkey" in the cyclical system and the 5th day was "white.216.hu" in the cyclical branch, it was the 5th October' (Tai4).

$\checkmark$ GREAT sen Six White lu ay dur MONTH liauqu teqoa orlabiń jur dur WHITE po DAY

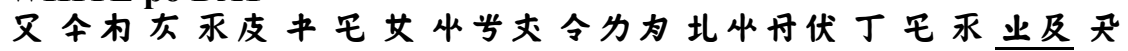
(373 244.140085005064122368081 261.362.118 047.168.189076.261. 311.222002368007295 .186159 )

$<$ GREAT s.en SIX WHITE lu ai dur MONTH l.iaū.qú t.qo.a or.l.b.ñ jur dur WHITE p.o DAY>

“寿昌六庚辰年四月丁西朔二十四庚申日' (《弘》20行)

'In the sixth year of the Great Sen, in the White Dragon year, in the month (of the) Red Chicken according to the cyclical system, on the twenty-fourth day, i.e. the [day of the] White Monkey] [On April 24th in the 6th year of Shouchang] $]^{65}$ (Hong 20).

Note: $<$ GREAT sen SIX $>$ is Shouchang, the year 1095, the sixth year is 1101, the White Dragon (灰永皮 $\neq$ ) year, the fourth month is Red Chicken (坐䒓丈今カ为) in the cyclical system, the twenty-fourth is the White Monkey (永业及) day, that is the 24th April 1101.

$\checkmark$ te ay u'ulpar emu MONTH GOLD po orlabir jur SIX hariu teqoa DAYde

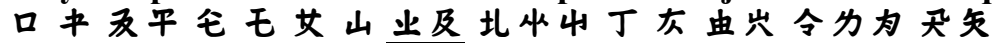

$<$ te ai u.ul par emu MONTH GOLD p.o or.l.bir jur SIX har.iú t.qo.a DAY.de> (323 122131.366240026081285295 .186076 .261 .288002085321 .289 247.168.189 159.205)

‘该年冬十一月戊申 朔二十六癸酉日于'(《显》26行)

\footnotetext{
${ }^{64}$ In other words: the cyclical stem and cyclical branch of the first day of October is bing shen, and that of the fifth day is geng zi.

${ }^{65}$ The same as example above, 承皮 (庚辰), 夾号丈今为 (丁酉) and 承业及 (庚申) denote the cyclical stems and cyclical branches, meaning the 6th year of Shouchang is Year geng chen, and the cyclical stem and cyclical branch of the first day of April is ding you, and that of 24th day of April is geng shen.
} 
'(in) that year, (in) winter at the eleventh month, the yellow (gold) monkey in the cyclical system, on the twenty-sixth day, the day of the Black(?) Chiken, November 26' (Xian26).

Note: 'On November 26th in this winter (山业及) 戊申 and (由岀今力为) 癸西 here denote the cyclical stems and cyclical branches. 圠夾山朔 means the first day of the lunar month. In the context, they mean that the cyclical stem and cyclical branch of the first day of November is wu shen, and that of 26th day of November is gui you (Xian26).

Examples for 业及及 $(295.186 .186)<$ p.o.o > 'monkey':

$\checkmark$ GREAT uduo'on naim gariu po'o ay nai MONTH jur gor DAYde eur SIXTY dolde

又米开及内丕由岀业及及未穴女丁包天矢古交又居矢

(373 355.090.186.322007321.289 295.186.186122332081002166159.205 $067.097266141 .205)$

$<$ GREAT udu.ó.o.ón naim har.iú p.o.o ai nai MONTH jur gor DAY.de eu.úr SIXTY dol.de>

'大安八王申 年正月二十三日于 岁六十七于' (《南》26行)

'The year (was) the 8th in the Great Peace (Daan) [period] the year of the Black Monkey, it was the first month and the twenty-third day (when he) died in his age of sixty-seven, [on January 23th 1091]' (Nan26) (Year: ren shen)'.

$\checkmark$ iši MONTH par nayir DAY po'o podo 忝女壬王天业及及非朱

$<$ iši MONTH par nayir DAY po.o.o po.do>

(033081240007 159 295.186.186 279.217)

九月十五日申时于《显》16行

'(In the) 9th month, eighteen(th) day, Monkey hour (shen 申3-5 PM), [September 15] (Xian16)'

$\checkmark \quad$ ciruen siu ui ay nair MONTH gariu po'odo DAY

机化当承夹平女由岀业及及天

$<$ ci.ru.én siu ui ai nair MONTH har.iú p.o.o DAY>

(162.236.361004 262122007081321.289295 .186 .186 159)

“次辛亥年八月王申日' (《玦》34行)

'In the second (or following) White Pig year (Xinhai 辛亥), the eighth month, the Black Monkey Day'

- po 业及 $(295 / 311.186)<$ p.o> 'appoint, promote, become' (Index 7×) | Mo bol- 'to become' HN bol- 'to become, to be, to be possible, or allowed' ${ }^{66}$, see SH 57§ Qutulayi qahan bolqaba ${ }^{67}$ (Index 7×). Orthographic variant: bo 丹及 $(311.186)<$ b.o $>$ (Index 1×).

* pōr 止及众 $(295.186 .255)<$ p.o.ri $>$ > 'made, caused to be [promoted to a position]' (K84, 112, Xiang5-21, 21-24, 24-37, 26-9, 27-30, 27-37, DiX56) (Index 96×), past tense. Orthographic variants: 止及圠 (295.186.076) $<$ p.o.or $>$ (Index 2×), 丹及今 $(311.186 .255)<$ b.o.ri ${ }_{5}>($ Index 14×).

\footnotetext{
${ }^{66}$ Not $o l$ - 'to find, to earn a living', $\mathrm{HN}$ ol- 'to find, to get, to obtain', nowhere $h$ - in MMo.

${ }^{67}$ Shimunek (2014) suggests MMo bü 'to be' which is improbable.
} 
$\checkmark$ jautau bo'ori 疗乎丹及企 $(015.029311 .186 .255)<$ jau tau b.o.ri ${ }_{5}>$ 'became a jau tau (Chaotao 招討), a punitive comissioner' (DiX 5-4/6 WJ 67),

$\checkmark \quad$ tau ayde xung ngii giuungun puu giuung šï bori

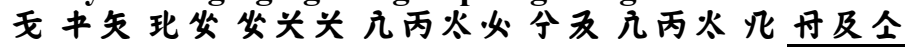
$<$ tau ai.de xu.ng ng.i.i g.iu.ung.un pu.u g.iu.ung shï b.o.ri $\underline{5}_{5}>$ (029 122.205 036.264 264.339.339 334.019.345.273 241.131 334.019.345 180 311.186.255)

“五年于弘义宫之副宫使拜’ (匹16-32 )

'(was) appointed to fugongshi in Hongyigong in the fifth year' (Wu16-32)

$\checkmark$ šiu mi pu šï bori 文岀头分灯再及全

$<$ sh.iú m.i pu shï b.o.ri 5

(028.289 133.339 $241180 \underline{311.186 .255})$

“枢密副使除”（许13-34）

'(he was) appointed to shumifushi'(Xu 13-34).

† *pol- 业及子 $(295.186 .149)<$ p.o.l $>$, also once 业及子 (295.131.149) $<$ p.u. $1_{2}>^{68}$ 'to become, be appointed, promoted to' (K50, 96, Sh2), same as above ${ }^{69}$, occurs only in derivated or conjugated stems as:

* poleliń 止及子夾伏 $(295.186 .149 .261 .222)<$ p.o.12.1.ń> past tense, feminin in:

$\checkmark \quad$ iu poleliń 丙止及子㭌伏 $(019$ 295.186.149.261.222) <iu p.o.l 2.1 .ń> 'she became nothing, she died' (Xiang14-27), yu is the negative existential, -luń finite past tense feminine, see Old Turkic yok bol-.

* polii 业及子比 $(295.186 .149 .077)<$ p.ol $_{2}$.ii $>$ converb in:

$\checkmark \quad$ šen polii 无去业及子圠 (028.073. 295.186.149.077)

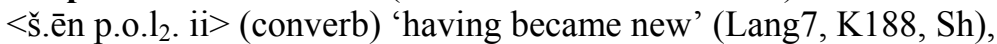

* polbuń 业及子丹伏 $(295.186 .149 .311 .222)<$ p.o.l 2. b.ń> past tense, in:

$\checkmark$ sïtu polbuń 进分止及子丹伏(028.202 295.186.149.311.222)

<sï tu p.o.l. 2 .b.ún> '(he) became Minister over Masses (situ 司徒) (of Huangci)' (Xiang24-28),

$\checkmark$ orci bolbun 圠机丹及子丹及(076.162 311.186.149.311.144)

$<$ or.ci b.o.l $l_{2}$.b.ún> '(he) became Orci' (DiX44-9/10) ${ }^{70}$.

* *polga- 业及子籴 $(295.186 .149 .051)<$ p.o.l 2 .ha $>$ factitive, Index $2 \times$ in:

* polġa'ai 业及子走中 $(295.186 .149 .051 .122)<$ p.o.l. ha.ai $>$ converb of the factitive stem, Index $49 \times$ in:

$\checkmark \quad$ kusu polġa'ai 几止业及子芷キ (178.372.041295.186.149.051.122)

$<$ ku.ū.su p.o.l $1_{2}$.ha.ai $>$

'the favour was granted' (Xiang4-19).

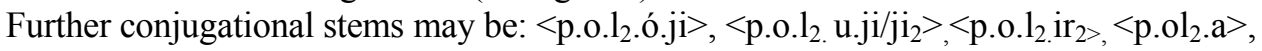
$<$ p.ol 2 .b.ń $>(12 \times)$.

\footnotetext{
${ }^{68}$ Once in <p.u.1.b.ń > in Zhen38-31.

${ }^{69}$ The glyph 子 (149) was read according to $\mathrm{WJ}<\mathrm{ju}>, \mathrm{K}<\mathrm{ju}>, \mathrm{Wu}<\mathrm{l}_{2}$. $>$.

${ }^{70}$ The glyph 圠 (076) was earlier read $<$ ho $>$.
} 
- *pulu- 业干 $(295.366)<$ p.ul > 'to be left over, to remain' | MMo hüle-, Mo üle- 'to be left over', Da huluu 'more than, over', DaE xul- 'to remain, to be left over', in

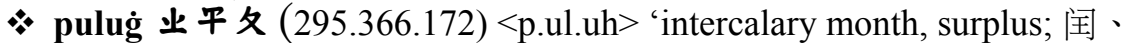
越《太》4 、 《于》60' (K103, Tai4, Yu60, Xiang2-27, 41-9, 44-20, WJ142, Sh, Index 17×)|MMo hülewü, Mo ülegü, ilegüü 'much, excess, surplus' Da hüledee- 'remain behind', DaE xulu 'surplus', cf. Ma fulu 'surplus'.

* pulugiiń 业千夕伏 $(295.366 .172 .222)<$ p.ul.uh.ń> (Index $2 \times)$ genitive case

* puluġun 止午必 $(295.366 .172 .273)<$ p.ul.uh.un> genitive case.

* pulugci 业平各约 $(295.366 .172 .337)<$ p.ul.uh.ji $>$ nomen actoris in -ci (X38-9). See also $<$ p.ul.u.ji $>$, $<$ p.ul.ō.ji $>$, $<$ p.ul.271.ji $>,<$ p.ul.271.hu $>$, $<$ p.ul.u.ń $>$ etc.

pür 止交 (295.097) 'descendant, offspring' | MMo hüre, Mo üre 'seed, offspring, descendants', Da hure, DaE xur (Index 4×).

* püres 业交全 (295.097.244.) <p.úr.s> 'descendants, plural' (WJ170-171).

Index $58 \times$.

$\checkmark$ pures EIGHTder u'urai 业交全爸公及化中 (295.097.244 008254.341131 .236 122) < p.úr.s EIGHT.d.er u.ur ai> '[as to the descendants of the 8th forefather] the eighth forfather was...' (DiX2-24/25)

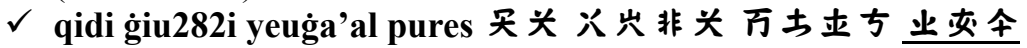
(365.339 340.289.282.339 020.067.051.098 295.097.244)

$<$ qid.i h.iú.282.i y.eu.ha.al p.úr.s>

'the descendants brought up (?) by the Khitan Giu282i [name]' (DiX224/25)

$\checkmark$ ay pures gi cier 丰业交全动机公(122.295.097.244336 162.341)

$<$ ai p.úr.s gi $i_{2}$ ci.er> '[his] male descandants were not recorded' (DiX2617/20).

$\checkmark$ aid THREEen ġuTENTgu pures ńu'ur 中爸包林列列业交全伏公交

(122.254 167.140 151.379.151 295.097.244 222.372.097)

<ai.d THREE.en hu.TENT.hu p. úr.s ń.ū.úr>

'the descendant lineages of the three fathers, the HuTENThu' (Xiang615/19).

Also Index: <p.úr.s.de.hu>, <p.u.r.s.b.ń>.

The glyph 斗 (297) was formerly read as $\langle\mathrm{pu}>$, but should be now read as $<$ gú $>$.

Khitan personal names with $<\mathrm{pu}>$ 分 $(241)$ :

$\checkmark$ Pusuli 分长分炎 $<$ Pu.su.û.oi $>$ (241.041.372.347) 'Pusuli (name of a person) 蒲速里 (人名), occurs in:

ciruen Purbiń puisiń tau'un uru eugińir gu'u taišien baqo Pusu'u’oi taiuide u'ulge'en 


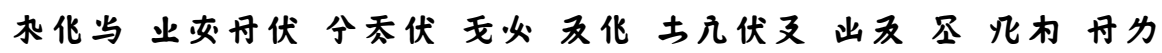

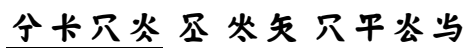

$<$ ci.ru.én p.úr.b.ñ pu.is.ñ tau.un u.ru eu.g.ñ.ir 2 gú.u tai ši.en b.qo pu.su.ū.oi tai ui ${ }^{\circ}$.de ū.ul.ge.én>

(162.236.361 295.097.311.222 241.033.222 029.273 131.236 067.334.222.144

297.131374180 .140311 .168241 .41 .372 .347374263 .205 372.366.349.361)

“次口夫人五院欧昆骨欲太师之子蒲速里太师于嫁” 《详》18.

'The second (daughter) Lady (furen) Purbiń was married to the son of Eugniir Guu taishi of the Five Divisions, [namely] to the Grand Commandant (taiwei) Pusuli'. (Xiang 18-31)

Note: the glyph 炎 may be a mistake, written instead of $x(269)<$ er>, and the Khitan name may have been *Busur, or Busuri.

- Punuń 分必瓜伏 $<$ Pu.un.u.ñ> (241.273.131.222) ‘盆奴（人名）'. 'Punuń (name of a person)'

$\checkmark$ ya LUCKń tirbir taiši deu ay Punuń teqosir ca'ang šu

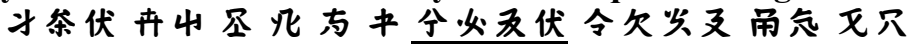

(335.277.222 074.288374180101122 241.273.131.222 247.169.354.144 375.199 028.372)

$<$ ia LUCK.ñ tir.bir tai shï deu ai pu.un.u.ñ t.qó.s $\mathbf{s}_{2} . \mathrm{ir}_{2}$ ca.ang sh.û>

‘胡暏堇铁离太师叔父盆奴图古辞尚书”回》4

'[Hudujin]tieli taishi’s uncle Punuń tuguci shangshu' (Hui 4-1/10).

Chinese words with 今 $<\mathrm{pu}>(241)$ :

- puši 分忝 $241.033<$ pu.ši > 'deputy commissar' (DiX2-1, 27-1, 29-12) Ch fush $i$ 副使 LMCh fjyw, fuw, EMCh $p u w^{h}, \mathrm{LMCh}_{s} s$, EMCh $s i, s i$, (WF747, Di2-1, 27-1,29-12). Index: <pu-ši $>8 \times$,

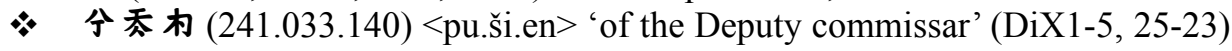
$<$ pu.ši.en> $2 \times$, in:

分忝机百爸业キ圣 $(241.033 .140021 .254295 .123$ 134) < pu.ši.en mo.d p.ar TWO $>$ 'the two wives of the Deputy Commissar' (DiX25-24/25).

- püšiń 分芜伏 $(241.033 .222)<$ pu.ši.ño > madam, Lady (Index 137×), Ch furen 夫人 LMCh fjalfua, LMCh rin, EMCh pua, EMCh nin' (K23, 39, 62, 104, Sh 106, WJ 53, DiX8-21, 9-4, 12-18, 13-3, Xiang8-23, 12-36, 13-6, 13-31, 14-6, 18-20, 18-34, Xu9, Index 136×) | MMo SH hüjin $\|(033)^{71}$ and (221) have dotted forms (034) 忝 and (222) 伏 resp. Though the inscription Pu uses the glyph $<\mathrm{fu}>$ 分 (242), the title furen is written 8 times and only with 分 $<\mathrm{pu}>$. In most cases in Pu the glyph fu 分 (242) is the transcription of different Chinese syllables sounding /fu/. This means that püsin 分荬伏 (241.033.222) became a loanword, it became a Khitan word.

* pušińen 分枲伏本 $(241.033 .222 .140))$ < pu.ši.ń.en> 'of the lady, madam' (Index 36×) genitive case (DiX12-1, Xiang13-26, 33-35, 45-8).

\footnotetext{
${ }^{71}$ See Róna-Tas (2016: 129) on the reading of (033), otherwise logograph for NINE.
} 
* pušińde 分忝伏矢 $(241.033 .222 .205)<$ pu.ši.ń.de> Index 2×, dative-locative

* pušińdei 分忝伏矢头 $(241.033 .222 .205 .339)<$ pu.ši.ń de.i> (Index 1×), morphologically yet not clear.

Khitan words with $<\mathrm{pu}>$ 今 $(241)$ :

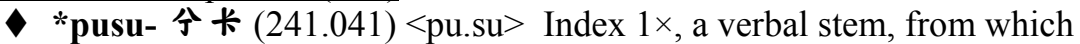

* *pusulge-/pusu'ulge- 分长夾㕕/会 (241.041.261.112/349)<pu.su.l.ge 2 /ge>

*分长分夾㕕/㕕<pu.su.ū.l.ge $/$ ge $>(241.041 .372 .261 .112 / 349)$ a factitive secondary stem, also

*分长分平九 $(241.041 .372 .366 .334)<$ pu.su.û.ul.g> 'to celebrate, $\mathrm{Ch}$ 庆' in:

ol RECORDe ku pemu 282 curubiń xaše ciqui pusu'ulg juruġ yu

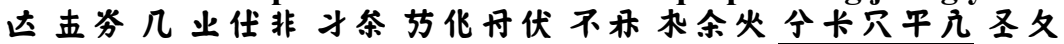
万斥

$<$ ol RECORD.e ku p.mu. 282 cu.ru.b.ñ xa.she ci.qu.ui pu.su.û.ul.g jur 2 .uh y.u $>$

(115 052.1.348 178 295.224.282 335.277 102.236.311.222 130.315 162.

246.262 241.41.372.366.334 134.172 020.131)

‘众 $\square$ 人余福积时汉儿庆 $\square \square$ ' 《宋》17,

'...celebrate when many ... people accumulate good fortune Han people ${ }^{72}$, (Song17-17/26)

* pusu'ulci- 分长分平机 $(241.041 .372 .366 .162)<$ pu.su.û.ul.ci> 'to prosper, Ch 兴' (Zhi8), in:

suien DAY yeuji polbir nadbodo amad pusulci iri $307 y$ yieriu abu'ul aulġa'alir

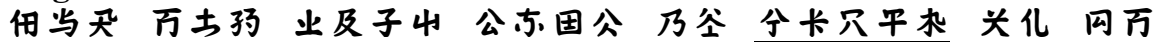
石文布及全仅丸干立万及

(238.361 159 020.067.152 295.186.149.288 251.099.309.253 184.254 241.41. 372.366.162 339.235 307.020 020.327.084.131 196227 161.366.051.098.144) $<$ sui.én DAY y.eu.ji p.o.1 2 .bir n.ad.bod.ô ${ }_{2}$ am.d pu.su.û.ul.ci i.ri 307.y y.ie.ri ${ }_{6} . u$ abu ul au.ul. ha.al.ir $>>$

“生日行成为行帐涌泉涌出号 $\square$ 太平阿不 $\square$ 改” 《智》8

'Birthday walk become,... temporary imperial tent (Nabo)... spring poured out the title...peace Abu .... was changed' (Zhi8-36/48)

* pus'ulger- 分长下干㕕及 $(241.41 .372 .366 .349 .144)<$ pu.su.û.ul.ge.ir ${ }_{2}>$ 'to celebrate, commemorate, $\mathrm{Ch}$ 庆' in:

$\checkmark$ gur pusu'ulger aluji om054i ora qagaan min bagańuede

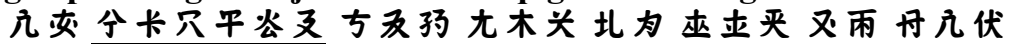
爸矢

$<$ g.úr pu. su.û.ul.ge.ir ${ }_{2}$ al.u.ji om.054.i or.a qa.ha.an m.in b.g.ñ.ū.e.de> (2016).

${ }^{72}<$ ci.qu.ui $>$ is one form of the Khitan names of the Han or Chinese people, see Róna-Tas 
(334.097 241.041.372.366.349.144 098.131.152 .339076.189053.051.011 133.018 311.334.222.372.348.205)

‘国庆 $\square \square$ 可汗之朝阿保谨于越于'《详》5,

'(the) country commemorated ... the royal funeral (qahaan min) for Abogin üge (Abaojin yuyue the founder of the Liao dynasty) (Xiang5-1/9).

The glyph po $<$ po $>$ 非 (279) occurs in:

$\checkmark$ po 非 (279)<po> 'time, year', (K19, 68, 122, DiX4-16-17, Sh2), Liao shi po 頗 LMCh $p^{h} u a$, EMCh $p^{h} a \mid$ MMo hon, Mo on, Da hoon, DaE xə:n, all data with $-n$, Index $42 \times$.

* podo 非朱 (279.217) < po.do> 'at the time', temporal-locative: (Jue221-41, 13-16, 18-44, 12-26, 5-43, 26-59, Hui9-20, Hu6-24, 11-46), Index 65×, in: hongdiin podo 主王雨非朱(075.037.018 027)

$\checkmark<$ hoy.di.in po.do $>$ 'at the time of the Emperor...' (DiX3-23/27),

$\checkmark$ te podo 口非朱 $(323.279 .217)<$ te po.do> 'in that time' (DiX 4-17, Xiang5-15) $)^{73}$

$\checkmark$ qahaden podo 來正牙非朱 $(053.051 .099$ 279.217) <qa.ha.ad.en po.do> 'in the time of the khans' (Xiang3-2),

* po'on 非了 (279.154) <po.on> genitive case (Hui11-9). Index 4×,

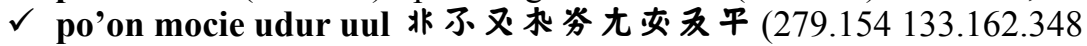

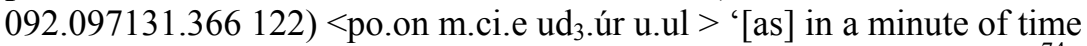
(poon möce), the winter (uul) was beginning (udur 'first')' (Di47-9/14) ${ }^{74}$.

* poji 非兴 $(279.354)<$ po.dz> 'season' from po 'time, year' and the suffix $-\mathrm{j} / \mathrm{dz}$, Index $5 \times$.

$\checkmark$ FOUR podze 导非兴 $(368279.354)<$ FOUR po.dz $>$ 'the four seasons' (Xiang30-7, 34-16),

podzen 非兴术 < po.dz.en> (279.354.140) genitive case $1 \times($ Dao17-2)

* podzer 非兴会<po.dz.er> (279.354.341) accusative-instrumental case (Liang20-22)

pong: <pong> 羔 (360)

According to Kane (K78) < pong > 羔 (360) is a compound character made from $<\mathrm{p}>$ 止 (295) and <ong $>$ 黑 (071), used to transcribe only Chinese syllables as fang 方. But even this may be rare. It does not occur in Index as initial.

\section{Summary}

In the material we find words with alternating $\langle\mathrm{p}>$ - and $\langle\mathrm{b}>$ - initials and words with $<\mathrm{p}>$ - not alternating with $<\mathrm{b}>$-. The Romanisation $<\mathrm{b}>(\sim<\mathrm{p}>)$ may reflect a voiceless

${ }^{73}$ Glyph (332) was earlier read $<$ qi $>$.

${ }^{74} \mathrm{Wu}$ read $t$ (092) as $<$ om $>$. 
unaspirated stop. Whether it was a strong /p/ or a weak bilabial stop /b/ remains open, but for technical reasons we opt for $<\mathrm{b}>$.

In the cases where $<\mathrm{p}>$ did not alternate with $<\mathrm{b}>$ we have two options. (1) It had a variant with $<\mathrm{b}>$, but this did not occur or was not identified yet, (2) the sound was an aspirated strong bilabial stop $/ \mathrm{p} \%$

This aspirated strong bilabial stop disappeared in most Modern Mongolic languages through $/ \mathrm{h} /$, but $/ \mathrm{h} /$ or its further continuations were preserved in Middle Mongolian, and are present in some archaic Mongolic languages, among them in Dahur as $/ \mathrm{h} /{ }^{75}$. In our material we found:

Khitan par(a) MMo harban, Mo arban 'ten', Khitan pülüg $~$ MMo hülewü, Mo ülegü 'surplus', Khitan püre(s) MMo hüre, Mo üre 'seed, descendants', Khitan po $\sim$ MMo hon, Mo on 'year', and as a loan from Chinese: Khitan pušiń $\sim$ MMo hüjin 'lady, princess'.

For Khitan we have the following rule of representation:

\begin{tabular}{|l|l|l|l|}
\hline Khitan phoneme & $\begin{array}{l}\text { Romanisation of } \\
\text { the Khitan glyph }\end{array}$ & $\begin{array}{l}\text { Middle Chinese } \\
\text { phonems }\end{array}$ & $\begin{array}{l}\text { Modern Chinese } \\
\text { pinyin }\end{array}$ \\
\hline$/ \mathrm{p} /$ & $<\mathrm{p}>$ & $/ \mathrm{ph} /, / \mathrm{ph} /, / \mathrm{fh} /, / \mathrm{fj} /$ & $<\mathrm{p}>,<\mathrm{f}>$ \\
\hline$/ \mathrm{p} /$ & $<\mathrm{b}>$ & $/ \mathrm{p} /$ & $<\mathrm{b}>$ \\
\hline
\end{tabular}

As we can see, the opposition of labial stops was based on the existence of postaspiration and its lack. However, we find many words in the case of which the initial $<p>$ and $\langle\mathrm{b}>$ alternated. This may mean that the aspiration was not very strong or this alternation may be due to the weak points of the Khitan Small Script. On the other hand, postaspiration was phonologically relevant and could be traced later. An argument in favour of this statement is that $/ \mathrm{p}^{6} /$ became $/ \mathrm{h} /$ in Dahur ${ }^{76}$.

\section{Signs used}

$\checkmark \quad$ independent lexical item

* derivation or morphologically extended item

example from the Corpus

\section{Abbreviations}

$A=$ Aisin Gioro (2012)

$\mathrm{BaoD}=$ Dahejia (or Jishishan) Baoan (after HN)

${ }^{75}$ The history and later representations of the Proto Mongolian * $\mathrm{p}^{*}$ - has been dealt with the last time by H. Nugteren (2011: 250-257).

${ }^{76}$ Some authors suppose that Dahur is a heavily Mongolised Khitan dialect, other authors think that the clear parallels between Dahur and Khitan are due to archaic features preserved in Dahur. 
BaoŃ = Ńantoq subdialect of Tongren Baoan (after HN)

$\mathrm{C}=$ Chinggeltei (2002)

$\mathrm{Ch}=$ Chinese

$\mathrm{Da}=$ Dagur according to Martin (1961)

$\mathrm{DaE}=$ Dagur according to Enkhbat (1984) (cited from HN)

Dao $=$ The Daozong inscription (AD 1101), ed. LK

Dgx $=$ Dongxian (after HN)

DiX = Xiao Dilu inscription (AD 1114) in WJ

EMCh $=$ Early Middle Chinese according to Pulleyblank (1991)

$\mathrm{Eyu}=$ Eastern Yugur after HN

$\mathrm{GQ}=$ Gansu Qinghai Mongolian

$\mathrm{Gu}=$ The Gu Yelü shi mingshi inscription (AD 1115), ed. LK

$\mathrm{HN}=\mathrm{H}$. Nugteren (2011)

$\mathrm{Hu}=$ The Xiao Hudujin inscription (AD 1091), ed. Wu (2012)

Hui $=$ The Xiao Huilian inscription (AD 1080), ed. Wu (2012)

Hui gai $=$ The cover of the Xiao Huilian inscription (AD 1080), ed. Wu (2012)

Index $=$ The Index to Chinggeltei, Wu Yingzhe and Jiruhe (2017)

Jue $=$ the Yelü Jue inscription (AD 1071), ed. Wu (2012)

$\mathrm{K}=$ Kane (2009)

$\mathrm{Kgj}=$ Kangjia, a Baoanic language (cited fom $\mathrm{HN}$ )

KLS $=$ Khitan Large or Linear Script

KSS $=$ Khitan Small or Assembled Script

Lang $=$ The Langjun inscription (AD 1134) in K186-189

Lang2 $=$ The Langjun inscription according to Sh2

$\mathrm{LCh}=$ Liao Chinese

Liang $=$ The Liang guowang inscription (AD 1107), ed. LK

List $=$ List of KSS graphs as in WJ 258-272

LK $=$ Liu Pujiang and Kang Peng (2014)

$\mathrm{LMCh}=$ Late Middle Chinese according to Pulleyblank (1991)

$\mathrm{Ma}=$ Manchu according to Norman (1967)

$\mathrm{MaH}=$ Manchu according to Hauer (1952-1955)

Mgr $=$ Smedt and Mostaert (1933)

$\mathrm{MgrH}=$ Huzhu dialect of Monguor (after HN)

MgrM $=$ Minhe dialect of Monguor (after HN)

MMo $=$ Middle Mongolian

Mo $=$ Literary Mongolian according to Lessing (1960)

Nan $=$ The Yelü Dilie inscription (AD 1092) in K 191

$\mathrm{Nu}=$ The Yelü $N u$ inscription (AD 1099)

$\mathrm{PC}=$ The cover of the Yelü Pusuli inscription (AD 1105), ed. Wu (2012)

$\mathrm{PU}=$ The Yelü Pusuli inscription (AD 1105), ed. Wu (2012)

$\mathrm{QG}=$ The Qinghai and Gansu Mongol languages according to HN

Qing = The Yongqing inscription (AD 1095), ed. LK

$\mathrm{SH}=$ The Secret History of the Mongols (cited after Rachewiltz 1972 and 2004)

$\mathrm{Sh}=$ Shimunek $(2011)$

Sh2 $=$ Shimunek (2014)

Sh17 $=$ Shimunek (2017)

$\mathrm{SJL}=$ Sun Bojun, Jing Yongshi and Li Yang (2010)

Song = the Song Wei inscription (1110), ed. LK 
Tai $=$ The Taishuz $u$ inscription (1110), ed. LK

$\mathrm{Tib}=$ Tibetan

TMR = Tibeto-Mongolica Revisited (Róna-Tas 2014)

$\mathrm{Tu}=$ The Tuguci inscription (AD 1068), ed. LK

WF $=$ Wittfogel and Fêng (1949)

$\mathrm{WJ}=\mathrm{Wu}$ Yingzhe and J. Janhunen (2010)

WOT= Róna-Tas and Berta (2011)

$\mathrm{Wu}=$ The Fubushu inscription (AD 1102), ed. LK

Wu17 $=$ Wu Yingzhe, Jiruhe and Peng Daruhan (2017)

Xian $=$ The Xiao Jushi inscription (AD 1175), ed. LK

Xiang $=$ The Yelü Xiangwen inscription (AD 1091), in WJ

Xing $=$ The Xingzong inscription (AD 1105), ed. LK

$\mathrm{Xu}=$ The inscription of Xuguo (AD 1105), ed. LK

Xuan $=$ The Eulogy for Empress Xuanyi (AD 1101), ed. K 214-223

$\mathrm{Yu}=$ The Renxian inscription (AD 1072), ed. LK

Zhi $=$ The Zhixian inscription (AD 1094), ed. LK

Zhong $=$ The Xiao Zhonggong inscription (AD 1150)

\section{References}

Aisin Gioro, Ulhicun [Yoshimoto Chieko] 吉本 智慧子 2012. 'Kittan shoji no onka suitei oyobi sōkan mondai 契丹小字の音価推定及び相関問題 [Reconstruction of phonetic values of Khitan Small Scripts and concerning problems].' Ritsumeikan bungaku 立命館文學 627: 100-128. (Online version: http://www.ritsumei.ac.jp/acd/cg/lt/rb/627/627PDF/yosimoto.pdf, last access: 10 December 2018.)

APATÓCZKY, Ákos Bertalan and Béla KeMPF 2017. 'Recent developments on the decipherment of the Khitan Small Script.' AOH 70/2: 109-133.

BAXTER, William Hubbard 1992. A Handbook of Old Chinese Phonology. Berlin and New York: Walter de Gruyter.

ChingGelter 2002. 'On the Problems of Reading Kitan Characters.' AOH 55/1-3: 99-114.

(ChINGGELTEI) QINGGEERTAI 清格尔泰, Wu Yingzhe 吴英吉吉 and JiRUHE 吉如何 2017. Qidan xiaozi zai yanjiu 契丹小字再研究 $I-I I I$. [Further research on Khitan Small Script]. Beijing: Neimenggu Daxue Chubanshe.

Golden, Peter (ed.) 2000. The King's Dictionary. The Rasülid Hexaglot. Fourteenth Century Vocabularies in Arabic, Persian, Turkic, Greek, Armenian and Mongol. [Handbuch der Orientalistik. Achte Abteilung, Zentralasien (Book 4).] Leiden, Boston and Köln: Brill.

EnKHBAT 1984. Dagur kelen-ü̈̈̈ges [Dagur-Chinese Dictionary]. Kökekota.

HAUER, Erich 1952-1955. Handwörterbuch der Mandschusprache I-III. Wiesbaden: Harrassowitz.

KAŁUŻYŃSKI, Stanisław 1969-1970. 'Dagurisches Wörtervezeichnis. Nach F. V. Muromskis handschriftliche Sprachaufzeichnungen.' Rocznik Orientalistyczny 33/1: 103-140, 33/2: 109-143.

Kane, Daniel 2009. The Kitan Language and Script. Leiden and Boston: Brill.

KARLGREN, Bernhard 1957. Grammata Serica Recensa. Stockholm: Museum of Far Eastern Antiquities.

LeSsing, Ferdinand D. (ed.) 1960. Mongolian-English Dictionary. Berkeley and Los Angeles: University of California Press. 
LIU Pujiang 刘浦江 and KANG Peng 康鹏 (eds.) 2014. Qidan xiaozi cihui suoyin 契丹小字词汇 索引 [Lexicon and index to the words in Small Khitan (inscriptions)]. Beijing: Zhonghua Shuju.

Martin, Samuel E. 1961. Dagur Mongolian Grammar, Texts and Lexicon, Based on the Speech of Peter Onon. Bloomington: Indiana University; The Hague: Mouton \& Co.

NoRman, Jerry 1967. A Manchu-English Dictionary. Taipei: The Liberal Arts Press.

Nugteren, Hans 2011. Mongolic Phonology and the Qinghai-Gansu Languages. Utrecht: LOT.

Pulleyblank, Edwin George (ed.) 1991. Lexicon of Reconstructed Pronunciation in Early Middle Chinese, Late Middle Chinese and Early Mandarin. Vancouver: UBC Press.

RACHEwILTZ, Igor de 1972. Index to the Secret History of the Mongols. [Uralic and Altaic Series, vol. 121.] Bloomington: Indiana University.

Rachewiltz, Igor de 2004. The Secret History of the Mongols. A Mongolian Epic Chronicle of the Thirteenth Century. Vols. 1-2. [Brill's Inner Asian Library, vol. 7.] Leiden and Boston: Brill.

RÓNA-TAS, András 2014. Tibeto-Mongolica Revisited, with a New Introduction and Selected Papers on Tibetan Linguistics. Leiden and Boston: Brill.

RónA-TAS, András 2016. 'Khitan Studies I. The Graphs of the Khitan Small Script. 1. General Remarks, Dottes, Graphs, Numerals.' AOH 69/2: 117-138.

RÓNA-TAS, András 2017. 'Khitan Studies I. The Graphs of the Khitan Small Script. 2. The Vowels.' AOH 70/2: 135-188.

RÓNA-TAS, András and Árpád BERTA 2011. West Old Turkic. Turkic Loanwords in Hungarian I-II. Wiesbaden: Harrassowitz.

SHIMUNEK, Andrew 2011. 'Review of Daniel Kane: The Kitan Language and Script. Leiden, Brill, 2009.' AOH 64/1: 101-111.

SHIMUNEK, Andrew 2014. 'A New Decipherment and Linguistic Reconstruction of the Kitan-Chinese Bilingual Inscription of 1134 A.D.' $A O H$ 67/1: 97-118.

SHIMUNEK, Andrew 2017. Languages of Ancient Southern Mongolia and North China. Wiesbaden: Harrassowitz.

Smedt, A. de and A. Mostaert 1933. La dialecte Monguor parlé par les Mongols du Kansou Occidentale, III partie: Dictionnaire monguor-français. Pei'ping.

Sun, Bojun, Yongshi JiNG and Yang Li 2010. 'Preliminary Proposal for Encoding Khitan Characters in UCS. (ISO/IEC JTC1/SC2/WG2/N3820. 2010-04-15.)' (Online access: http://std.dkuug.dk/ jtc1/sc2/wg2/Docs/n3820.pdf, last access: 5 Febr. 2019.)

Svantesson, Jan-Olof et al. 2005. The Phonology of Mongolian. Oxford: Oxford University Press.

WitTFogel, Karl and FÊNG Chia-shêng 1949. History of Chinese Society: Liao (907-1125). Philadelphia: The American Philosophical Society.

WU Yingzhe 2012. Kittan shōji shinhakken shiryō shakudoku mondai 契丹小字新発見資料釈読 問題 [Interpretation problems of the newly discovered Khitan small script materials]. Tokyo: Tōkyō Gaikokugo Daigaku Ajia Afurika Gengo Bunka Kenkyūjo.

WU Yingzhe and Juha JANHUNEN 2010. New Materials on the Khitan Small Script, A Critical Edition of Xiao Dilu and Yelü Xiangwen. Folkestone: Global Oriental.

Wu Yingzhe, JiRUHE and Daruhan PeNG 2017. 'Interpretation of the Epitaph of Changgun Yelü Zhun of Great Liao in Khitan Large Script.' AOH 70/2: 217-251. 


\section{APPENDIX}

\section{Concordance Tables of the Khitan Inscriptions in the Khitan Small Script}

Remarks: Lately different numbers, sigla and short titles were given to different Khitan texts written with the Khitan Small or Assembled Script. To avoid further chaos, the Khitan Research Group of the Chinese People's Republic has standardised the Sigla for each major or greater inscription $(1-44)$ and for each minor or smaller inscription (S1-17). In the following table the standardised Chinese sigla are occurring in two forms, in Traditional Chinese $(\mathrm{Ch})$ and in Simplified Chinese (SCh). The Latin form of the sigla and the standard number is followed by the traditional and the simplified forms of the Chinese sigla, then follows, where known, the date of the inscription, the short name given by Apatóczky and Kempf (A-K, 2017) and Shimunek (Sh, 2017), the number given by Kane (K, 2009), by Wu and Janhunen (WJ, 2010), by Wu (Wu, 2012) and by Liu Pujiang and Kang Peng (LK, 2014).

\section{The Major Khitan Inscriptions in the Khitan Small Script}

In the Latin alphabetical order of the Sigla

\begin{tabular}{|l|l|l|l|l|l|l|l|l|l|l|}
\hline Sigla & No. & Ch & SCh & Date & $\begin{array}{l}\text { Short name } \\
\text { A-K }\end{array}$ & Sigla/Sh & K & WJ & Wu & LK \\
\hline Cha & 39 & 查 & 查 & 1113 & Xiao Chala & & & & 39 & \\
\hline Chao+gai & 27 & 抄+蓋 & 抄+盖 & 1082 & Cite/Wuluben & & 2 & 23 & 28 & 21 \\
\hline Da & 43 & 大 & 大 & 1073 & Gu Taishi & & & & & \\
\hline Dao+gai ${ }^{77}$ & 4 & 道+蓋 & 道+盖 & 1101 & Daozong & Tao & 3 & 4 & 04 & 3 \\
\hline Di & 21 & 迪 & 迪 & 1101 & Yelü Han & Hti & 10 & 19 & 21 & 23 \\
\hline DiX & 33 & 敵 & 敌 & 1114 & Xiao Dilu & HsTi & & 33 & 33 & \\
\hline Gao & 20 & 高 & 高 & unknown & Gaoshi & Kao & 6 & 15 & 20 & 25 \\
\hline Gu & 9 & 故 & 故 & 1115 & Gu Yelü & Ku & 7 & 8 & 09 & 7 \\
\hline GuD & 28 & 姑 & 姑 & 1102 & Diligu & Kuei & 8 & 29 & 27 & 29 \\
\hline Guang & 12 & 廣 & 广 & 1053 & Zongjiao & Chiao & 32 & 11 & 12 & 11 \\
\hline Hai & 11 & 海 & 海 & unknown & Hai tangshan & Hai & 9 & 12 & 11 & 12 \\
\hline Han & 26 & 韓 & 韩 & 1078 & Temei/Hanshi & & 21 & 32 & 26 & 32 \\
\hline Hong & 14 & 弘 & 弘 & 1100 & Honyong & Yung & 11 & 18 & 15 & 17 \\
\hline Hu & 35 & 胡 & 胡 & 1091 & Hudujin & HsHu & & & 35 & \\
\hline
\end{tabular}

${ }^{77}$ gai 盖 'canopy'. 


\begin{tabular}{|c|c|c|c|c|c|c|c|c|c|c|}
\hline Sigla & No. & $\mathrm{Ch}$ & $\mathrm{SCh}$ & Date & $\begin{array}{l}\text { Short name } \\
\text { A-K }\end{array}$ & Sigla/Sh & K & WJ & $\mathrm{Wu}$ & LK \\
\hline Hui+gai & 38 & 回+蓋 & 回十盖 & 1080 & Xiao Huilian & & & & $\begin{array}{l}38 \mathrm{KC}, \\
\mathrm{KL}\end{array}$ & \\
\hline Jue & 37 & 玦 & 玦 & 1071 & Yelü Jue & YChüeh & & & $36 \mathrm{JU}$ & \\
\hline Lang & 3 & 郎 & 郎 & 1134 & Langjun & Lang & 12 & 3 & 03 & 8 \\
\hline Liang & 31 & 梁 & 梁 & 1107 & $\begin{array}{l}\text { Liang } \\
\text { guowang }\end{array}$ & & 13 & 28 & 31 & 28 \\
\hline Ling & 6 & 令 & 令 & 1057(?) & Xiao Lingjong & & 31 & 7 & 06 & 5 \\
\hline Nan & 16 & 南 & 南 & 1092 & Dilie & YTi & 4 & 20 & 18 & 16 \\
\hline $\mathrm{Nu}$ & 17 & 奴 & 奴 & 1099 & Yelü Nu & & 15 & 25 & 20 & 24 \\
\hline $\mathrm{Pu}+$ gai & 36 & 蒲+蓋 & 蒲+盖 & 1105 & Pusuli & YP'u & & & $\begin{array}{l}37 \text { PC. } \\
\text { PU. }\end{array}$ & \\
\hline Qing & 25 & 清 & 清 & 1095 & Yongqing & & 28 & 30 & 25 & 30 \\
\hline Ren & 2 & 仁 & 仁 & 1076 & Renyi & Jen-i & 17 & 2 & 02 & 2 \\
\hline $\mathrm{Sa}+\mathrm{e}^{78}$ & 29 & 撒+蓋 & 撒+额 & 1100 & Shilu & & 18 & 26 & 29 & 26 \\
\hline Shi & 40 & 師 & 师 & 1101 & Taishi & & & & 40 & \\
\hline ShiZh & 41 & 侍 & 侍 & 1091 & Shizhong & & & & 41 & \\
\hline Song+gai & 24 & 宋+蓋 & 宋+盖 & 1110 & Song Wei & Sung & 19 & 22 & 24 & 20 \\
\hline Tai+gai & 23 & 太十蓋 & 太十盖 & 1110 & Taishuzu & T'ai & 20 & 21 & 23 & 19 \\
\hline Tian & 44 & 天 & 天 & 1109 & Tianni & & & & & \\
\hline $\mathrm{Tu}$ & 22 & 圖 & 图 & 1068 & Tuguci & & 22 & 27 & 22 & 27 \\
\hline Wo & 42 & 斡 & 斡 & 1099 & Wotelan & & & & & \\
\hline $\mathrm{Wu}$ & 30 & 兀 & 兀 & 1102 & Fubushu & $\mathrm{YFu}$ & 5 & 27 & 30 & 18 \\
\hline Xian+gai & 32 & 顯+蓋 & 显+盖 & 1175 & Xiao Jushi & & & 31 & 32 & 31 \\
\hline Xiang & 34 & 詳 & 详 & 1091 & Xiang Wen & YHsiang & & 34 & 34 & \\
\hline Xing & 1 & 興 & 兴 & 1055 & Xingzong & Hsing & 23 & 1 & 01 & 1 \\
\hline $\mathrm{Xu}+\mathrm{gai}$ & 8 & 許+蓋 & 许+盖 & 1105 & Xuguo & Xsü & 24 & 9 & 08 & 6 \\
\hline Xuan+gai & 5 & 宣+蓋 & 宣+盖 & 1101 & Xuanyi & Hsüan & 25 & 5 & 05 & 4 \\
\hline Yong & 19 & 永 & 永 & 1088 & Yogning & & 27 & 16 & 19 & 15 \\
\hline $\mathrm{Yu}$ & 10 & 於 & 于 & 1072 & Renxian & Jen-hsien & 16 & 10 & 10 & 10 \\
\hline Zhen & 13 & 鎮 & 镇 & 1170 & Zhenguo & Chen & 1 & 13 & 13 & 13 \\
\hline Zhi & 18 & 智 & 智 & 1094 & Zhixian & & 30 & 24 & 25 & 22 \\
\hline $\begin{array}{l}\text { Zhong+ } \\
\text { gai }\end{array}$ & 7 & 仲+蓋 & 仲+盖 & 1150 & $\begin{array}{l}\text { Xiao Zhong- } \\
\text { gong }\end{array}$ & Chung & 31 & 6 & 07 & 9 \\
\hline Zhuo & 15 & 溷 & 溷 & 1108 & Cishi & & 29 & 14 & 14 & 14 \\
\hline
\end{tabular}

${ }^{78} \dot{e}=$ 額 'front piece'. 


\section{The Minor Khitan Insciptions in the Khitan Small Script}

In the Latin alphabetical order of the Sigla, "S" for "Small"

\begin{tabular}{|c|c|c|c|c|c|c|}
\hline Sigla & No. & $\mathrm{Ch}$ & $\mathrm{SCh}$ & Date & Sigla/Sh & Description \\
\hline BaoS & S4 & 寶 & 宝 & unknown & & $\begin{array}{l}\text { Inscription on the back } \\
\text { of a Baodi Mirror }\end{array}$ \\
\hline $\mathrm{Ba}$ erS & S14 & 巴二 & 巴三 & unknown & & $\begin{array}{l}\text { Writings on the wall of the Bar } \\
\text { Hada Cave II }\end{array}$ \\
\hline Ba sanS & S15 & 巴三 & 巴三 & unknown & & $\begin{array}{l}\text { Writings on the wall of the Bar } \\
\text { Hada Cave III }\end{array}$ \\
\hline Ba yiS & S13 & 巴一 & 巴一 & unknown & & $\begin{array}{l}\text { Writings on the wall of Bar } \\
\text { Hada Cave I }\end{array}$ \\
\hline GuoS & $\mathrm{S} 2$ & 槨 & 橔 & unknown & & Writings on a Muguo Fresco \\
\hline QingS & S1 & 慶 & 庆 & unknown & & Writings on a Qinling Fresco \\
\hline Shous & S7 & 壽 & 寿 & unknown & & $\begin{array}{l}\text { Inscription on a Shouchang } \\
\text { Coin }\end{array}$ \\
\hline Ta erS & S12 & 塔二 & 塔二 & unknown & & $\begin{array}{l}\text { Writings on the wall of the Wan } \\
\text { Bu Hua Yan Jing Pagoda II }\end{array}$ \\
\hline Ta yiS & S11 & 塔一 & 塔一 & unknown & & $\begin{array}{l}\text { Writings on the wall of the Wan } \\
\text { Bu Hua Yan Jing Pagoda I }\end{array}$ \\
\hline WanS & S5 & 完 & 完 & unknown & & $\begin{array}{l}\text { Inscription on the back of a } \\
\text { Wanyantong bronze mirror }\end{array}$ \\
\hline YanS & S10 & 硯 & 砚 & unknown & & $\begin{array}{l}\text { Writings on a tricoloured glazed } \\
\text { inkstone and a yellow glazed } \\
\text { writing-brush washer }\end{array}$ \\
\hline YuS & S6 & 玉 & 玉 & unknown & & $\begin{array}{l}\text { Inscription on the Bottom } \\
\text { of a jade cup }\end{array}$ \\
\hline Yu erS & S9 & 魚二 & 魚二 & unknown & & $\begin{array}{l}\text { Inscription on a fish-shaped } \\
\text { tally (II) }\end{array}$ \\
\hline Yu yiS & S8 & 魚一 & 魚一 & unknown & Sh17: Yü1 & $\begin{array}{l}\text { Inscription on a fish-shaped } \\
\text { tally (I) }\end{array}$ \\
\hline YuanS & S3 & 圓 & 圆 & unknown & & $\begin{array}{l}\text { Inscription on the back } \\
\text { of a round bronze Mirror }\end{array}$ \\
\hline WuS & S16 & 烏 & 乌 & unknown & & $\begin{array}{l}\text { Writings on the cliff of } \\
\text { Ulaanhada }\end{array}$ \\
\hline YeS & S17 & 葉 & 叶 & unknown & & $\begin{array}{l}\text { Damaged epitaph found in } \\
\text { Yemaotai }\end{array}$ \\
\hline
\end{tabular}


